\title{
New composite bio- and isotope stratigraphies spanning the Middle Eocene Climatic Optimum at tropical ODP Site 865 in the Pacific Ocean
}

\author{
Kirsty M. Edgar ${ }^{1,2}$, Steven M. Bohaty ${ }^{3}$, Helen K. Coxall ${ }^{4}$, Paul R. Bown ${ }^{5}$, Sietske J. Batenburg ${ }^{6}$, \\ Caroline H. Lear ${ }^{1}$, and Paul N. Pearson ${ }^{1}$ \\ ${ }^{1}$ School of Earth and Ocean Sciences, Cardiff University, Cardiff, CF10 3AT, UK \\ ${ }^{2}$ School of Geography, Earth and Environmental Sciences, University of Birmingham, B15 2TT, UK \\ ${ }^{3}$ Ocean and Earth Science, National Oceanography Centre Southampton, \\ University of Southampton, SO14 3ZH, UK \\ ${ }^{4}$ Department of Geological Sciences, Stockholm University, 106 91, Stockholm, Sweden \\ ${ }^{5}$ Department of Earth Sciences, University College London, London, WC1E 6BT, UK \\ ${ }^{6}$ Géosciences Rennes, UMR 6118, CNRS, University of Rennes, Rennes, France
}

Correspondence: Kirsty M. Edgar (k.m.edgar@bham.ac.uk)

Received: 11 February 2020 - Revised: 9 June 2020 - Accepted: 11 June 2020 - Published: 27 July 2020

\begin{abstract}
The Middle Eocene Climatic Optimum (MECO) at ca. $40 \mathrm{Ma}$ is one of the largest of the transient Eocene global warming events. However, it is relatively poorly known from tropical settings since few sites span the entirety of the MECO event and/or host calcareous microfossils, which are the dominant proxy carrier for palaeoceanographic reconstructions. Ocean Drilling Program (ODP) Pacific Ocean Site 865 in the low-latitude North Pacific (Allison Guyot) has the potential to provide a useful tropical MECO reference, but detailed stratigraphic and chronological constraints needed to evaluate its completeness were previously lacking. We have addressed this deficit by generating new high-resolution biostratigraphic, stable isotope, and X-ray fluorescence (XRF) records spanning the MECO interval $(\sim 38.0-43.0 \mathrm{Ma})$ in two holes drilled at Site 865. XRF-derived strontium / calcium $(\mathrm{Sr} / \mathrm{Ca})$ and barium / strontium $(\mathrm{Ba} / \mathrm{Sr})$ ratios and $\mathrm{Fe}$ count records allow correlation between holes and reveal pronounced rhythmicity, enabling us to develop the first composite section for Holes $865 \mathrm{~B}$ and $865 \mathrm{C}$ and a preliminary cyclostratigraphy for the MECO. Using this new framework, the sedimentary record is interpreted to be continuous across the event, as identified by a pronounced transient benthic foraminiferal $\delta^{18} \mathrm{O}$ shift of $\sim 0.8 \%$ o. Calcareous microfossil biostratigraphic events from widely used zonation schemes are recognized, with generally good agreement between the two holes, highlighting the robustness of the new composite section and allowing us to identify planktic foraminiferal Zones E10-E15 and calcareous nannofossil Zones NP15-18. However, discrepancies in the relative position and ordering of several primary and secondary bioevents with respect to published schemes are noted. Specifically, the stratigraphic highest occurrences of planktic foraminifera, Acarinina bullbrooki, Guembelitrioides nuttalli, and Morozovella aragonensis, and calcareous nannofossils, Chiasmolithus solitus and Sphenolithus furcatolithoides, and the lowest occurrence of Reticulofenestra reticulata all appear higher in the section than would be predicted relative to other bioevents. We also note conspicuous reworking of older microfossils (from planktic foraminiferal Zones E5-E9 and E13) into younger sediments (planktic foraminiferal Zones E14-15) within our study interval consistent with reworking above the MECO interval. Regardless of reworking, the high-quality XRF records enable decimetre-scale correlation between holes and highlight the potential of Site 865 for constraining tropical environmental and biotic changes, not just across the MECO but also throughout the Palaeocene and early-to-middle Eocene interval.
\end{abstract}




\section{Introduction}

The transition from peak Eocene "greenhouse" conditions at $\sim 49-53 \mathrm{Ma}$ to the onset of the icehouse at $\sim 34 \mathrm{Ma}$ is punctuated by a number of transient climate events (e.g. Zachos et al., 2008; Bohaty et al., 2009; Edgar et al., 2007; Sexton et al., 2011; Hollis et al., 2019; Westerhold et al., 2018b). The most pronounced of these is the MECO event at $\sim 40 \mathrm{Ma}$ that represents a temporary reversal in the long-term Eocene global cooling trend (Bohaty and Zachos, 2003; Bohaty et al., 2009). The MECO event is characterized by ocean warming of $\sim 3-6^{\circ} \mathrm{C}$ (Bijl et al., 2010; Bohaty et al., 2009; Boscolo Galazzo et al., 2014; Edgar et al., 2010; Cramwinckel et al., 2018; Rivero-Cuesta et al., 2019), ocean acidification evidenced by $>1 \mathrm{~km}$ shoaling of the Pacific calcite compensation depth (CCD), and shifts in the global carbon cycle including a rise in atmospheric carbon dioxide concentrations (Bohaty et al., 2009; Pälike et al., 2012; Henehan et al., 2020; Bijl et al., 2010). Marine biotic responses vary across the event, impacting floral and faunal composition, body size, and ecology in the deep and surface ocean globally (e.g. Edgar et al., 2013; Witkowski et al., 2014; Möbius et al., 2015; Boscolo Galazzo et al., 2015; Luciani et al., 2010; Cramwinckel et al., 2019; Arreguín-Rodríguez et al., 2016).

The MECO is well known from mid- and high-latitude sites (e.g. ODP Sites 689, 690, 702, 748, 738, 1051, 1172 and 1263; Alum Bay in the UK; the Baskil section in Turkey; and the Alano, Contessa Highway, and Monte Cagnero sections in Italy), many of which also are characterized by good stratigraphic age control, comprehensive isotope stratigraphies, and carbonate-rich sediments yielding microfossils useful for proxy reconstructions (Edgar et al., 2010; Bohaty et al., 2009; Bohaty and Zachos, 2003; Bijl et al., 2010; Boscolo Galazzo et al., 2014; Spofforth et al., 2010; Jovane et al., 2007; Savian et al., 2013; Rivero-Cuesta et al., 2019; Dawber et al., 2011; Giorgioni et al., 2019). However, we currently lack a low-latitude site that unambiguously spans the pre-MECO, MECO, and post-MECO intervals and has continuous carbonate sedimentation uninterrupted by $\mathrm{CCD}$ or lysocline shoaling, thus recording environmental and biotic responses in the tropics.

Of the sites that do exist, ODP Site 1260 in the equatorial Atlantic has a high-resolution stable isotope stratigraphy that has been placed onto an astronomically tuned age model (Edgar et al., 2010; Westerhold and Röhl, 2013). However, interpretation of the MECO at this site is complicated by the lack of a clear return to higher $\delta^{18} \mathrm{O}$ values following the event and a hiatus which truncates the upper portion of the record (Edgar et al., 2010; Shipboard Scientific Party, 2004; Westerhold and Röhl, 2013). ODP Site 1218 and IODP Site U1333 in the equatorial Pacific Ocean both have good age control with comprehensive magnetic stratigraphies and astronomically tuned age models across the whole of the MECO interval (Westerhold et al., 2014; Expedition 320/321 Scientists, 2010), but their relatively deep palaeo-water depth
$(>3.3 \mathrm{~km})$, coupled with a relatively shallow Pacific CCD in the middle Eocene, resulted in little or no carbonate preservation across the peak of the event, preventing detection of its true magnitude (Expedition 320/321 Scientists, 2010; Westerhold et al., 2014; Pälike et al., 2012; Toffanin et al., 2013). Furthermore, no planktic foraminifera are present across the entire MECO interval at Site U1333 to constrain surfacewater conditions (Expedition 320/321 Scientists, 2010). Similarly, at shallower ODP Site $1209(\sim 2 \mathrm{~km}$ palaeo-water depth) in the subtropical North Pacific Ocean (Dutton et al., 2005) the interval containing the MECO has poor carbonate microfossil preservation, very low sedimentation rates, and thus, poor age control (Dawber and Tripati, 2011; Shipboard Scientific Party, 2002). ODP Site 711, in the tropical Indian Ocean has no carbonate preservation across the peak and initial post-MECO intervals $(\sim 3.5 \mathrm{~km}$ palaeo-water depth) (Savian et al., 2016; Peterson and Backman, 1990; Bohaty et al., 2009). Nearby ODP Site 709 has a much shallower palaeo-water depth of $2.2 \mathrm{~km}$ and moderate carbonate preservation, but the MECO is absent (Bohaty et al., 2009; Peterson and Backman, 1990). Finally, sediments from ODP Site 959 in the eastern equatorial Atlantic span the MECO but are organic-rich, poor in carbonate microfossils (planktic foraminifera are absent), and lack a robust magnetic stratigraphy (Cramwinckel et al., 2018).

Equatorial Pacific ODP Site 865 is an older site that has been rather neglected in Eocene palaeoceanographic studies. Drilled on Allison Guyot in 1992 on ODP Leg 143, the recovered cores sample a pelagic sediment drape $(\sim 200 \mathrm{~m}$ thick at the centre of the guyot and $\sim 140 \mathrm{~m}$ at Site 865 , which was drilled off-centre) that accumulated during the Palaeogene and early Neogene. The recovered sediments at the site are comprised of a succession of Palaeocene to Miocene foraminiferal-nannofossil ooze and foraminiferal sands (Shipboard Scientific Party, 1993b). The relatively shallow palaeo-water depths $(<2 \mathrm{~km})$ on the guyot top maximizes the preservation potential of carbonate microfossils, thus avoiding problems of CCD and lysocline shoaling encountered elsewhere at deeper sites in the Pacific (e.g. IODP Site U1333). Several Palaeogene-focused studies have highlighted the potential of this site for palaeoceanographic and evolutionary studies (Bralower et al., 1995; Tripati et al., 2003; Pearson and Ezard, 2014; Coxall et al., 2000; Pearson and Palmer, 2000; Edgar et al., 2015; Arreguín-Rodríguez et al., 2016; Norris and Nishi, 2001), but most of the hightemporal-resolution work has focused on the PalaeoceneEocene Thermal Maximum (PETM) (Kozdon et al., 2011, 2013; Kelly et al., 1996; Tripati and Elderfield, 2004) since ODP Site 865 is one of the few open ocean sites with carbonate present throughout the event.

Middle Eocene sediments at Site 865 have not received much attention for palaeoceanographic studies, in large part because of (1) poor quality of shipboard physical property records preventing the development of a composite section necessary to develop continuous stratigraphic sections; 
(2) the lack of magnetic reversal or cyclostratigraphy for age control; and (3) evidence for reworking of older calcareous microfossils into younger sediments, e.g. across the PETM onset and in the upper portions of the sediment column (Shipboard Scientific Party, 1993b; Bralower and Mutterlose, 1995; Kelly et al., 1998). Reworking and winnowing of sediment is an acknowledged problem of guyot-top sites where ocean currents can be locally intensified by the topography (Pearson, 1995). However, evolutionary studies have demonstrated that the calcareous microfossils (calcareous nannofossils and planktic and benthic foraminifera) are diverse and abundant, albeit recrystallized (Pearson et al., 2001; Sexton et al., 2006; Edgar et al., 2015; ArreguínRodríguez et al., 2016; Bralower and Mutterlose, 1995) and in the case of planktic foraminifera, provide an apparently complete sequence of tropical Palaeogene biomarkers and their lineage evolution (Norris and Nishi, 2001; Pearson and Ezard, 2014; Coxall et al., 2000). Importantly, existing biostratigraphic assessments for Holes 865B and 865C identify planktic foraminiferal Zone E12, defined by the total range of Orbulinoides beckmanni and spanning the MECO interval (Berggren and Pearson, 2005), and calcareous nannofossil Zone CN15/NP16 (Martini, 1971; Agnini et al., 2014), although there are large $(\sim 1 \mathrm{~m})$ recovery gaps between cores (Shipboard Scientific Party, 1993b; Bralower and Mutterlose, 1995; Pearson and Ezard, 2014). Core photos indicate the presence of carbonate-rich sediments throughout the entire middle Eocene interval of interest (i.e. there is no evidence of a clay horizon) providing a promising target for geochemical and plankton assemblage work (Shipboard Scientific Party, 1993b; Edgar et al., 2015; Pearson and Palmer, 2000).

Here we take the first step towards developing the ODP Site 865 MECO sequence as a palaeoceanographic reference by adding new datasets that allow development of a composite splice and a detailed chronostratigraphy for the site. This involves integration of high-resolution X-ray fluorescence (XRF) core scanning, benthic foraminiferal stable isotope $\left(\delta^{13} \mathrm{C}\right.$ and $\left.\delta^{18} \mathrm{O}\right)$, and planktic foraminiferal and calcareous nannofossil biostratigraphic data across the MECO interval at the site. These data are combined with published calcareous nannofossil datums (Bralower and Mutterlose, 1995) to (1) generate the first composite sedimentary section across the middle Eocene interval of Site 865, (2) identify and constrain the isotopic character of the MECO in the Pacific Ocean, and (3) determine the position of key biostratigraphic datums relative to the MECO event.

\section{Materials and methods}

\subsection{Regional setting}

ODP Site 865 was drilled during ODP Leg 143 and is located on Allison Guyot in the western North Pacific Ocean at $18^{\circ} 26.410^{\prime} \mathrm{N}, 179^{\circ} 33.339^{\prime} \mathrm{W}$ and a modern water depth of $1516 \mathrm{~m}$ (Shipboard Scientific Party, 1993b; Fig. 1). This

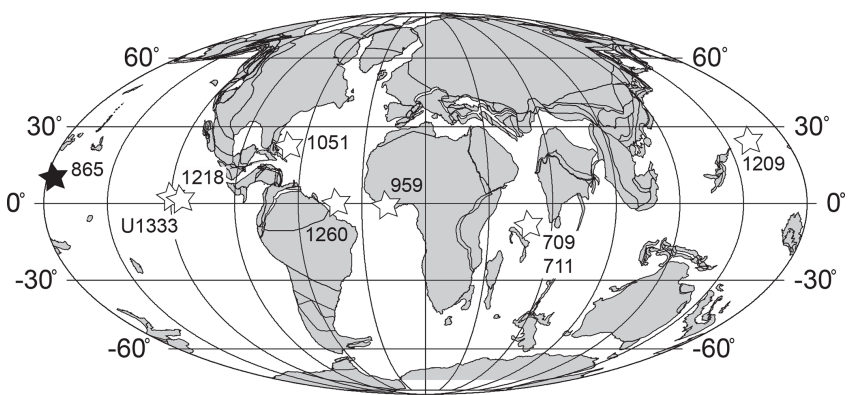

Figure 1. Location map for ODP Site 865 (solid star) and other low-latitude sites discussed in the main text (open stars) on a $40 \mathrm{Ma}$ reconstruction. Palaeolatitudes for each site are calculated from van Hinsbergen et al. (2015). Base map generated from http: //www.odsn.de (last access: 8 June 2018).

guyot is just one of a number of similar flat-topped volcanic seamounts in the region formed during the Cretaceous (e.g. Resolution and Wōdejebato guyots), which stand up to several kilometres above the surrounding abyssal $(>4 \mathrm{~km})$ seafloor (Shipboard Scientific Party, 1993a; Matthews et al., 1974). Three holes were drilled at Site 865 (A-C) with middle Eocene sediments only recovered in Holes B and C, which were cored with the aim of creating a continuous record of this interval. The middle Eocene sequence at Site 865 is positioned at shallow burial depths $(<100 \mathrm{~m})$ with no significant Quaternary cover. The foraminiferal nannofossil ooze and foraminiferal sands were deposited at $\sim 1300$ $1500 \mathrm{~m}$ palaeo-water depth based on benthic foraminiferal assemblages (Shipboard Scientific Party, 1993b) in a fully pelagic ocean gyre setting characterized by year-round thermal stratification (Pearson et al., 2001).

\subsection{X-Ray fluorescence (XRF) scanning}

XRF data are routinely employed for stratigraphic correlation and the construction of high-resolution composite depth scales because of their higher signal-to-noise ratio and more consistent hole-to-hole character than shipboard physical property measurements (Röhl and Abrams, 2000). Prior to $\mathrm{XRF}$ analysis, the top $\sim 0.5 \mathrm{~cm}$ of the split section surface of the archive halves was scraped off with a glass slide. This revealed bioturbation structures, indicating that this interval did not have significant coring disturbance (Fig. S1 in the Supplement), as might be expected from the foraminiferaooze lithologies and the massive appearance of the unprepared cores. Using an Avaatech XRF scanner with a Canberra X-PIPS SDD, Model SXD-150-500 X-ray detector, a suite of elemental (including $\mathrm{Fe}, \mathrm{Ca}, \mathrm{Sr}$, and $\mathrm{Ba}$ ) intensity data were collected every $2 \mathrm{~cm}$ down-core with a constant spot size (cross-core slot $=12 \mathrm{~mm}$; down-core slit $=10 \mathrm{~mm}$ ) using a 6 or $10 \mathrm{~s}$ count time at 30 and $50 \mathrm{kV}$, respectively, on the split surface of the archive half of each section using the TAMU ODASES XRF scanner at the Interna- 
tional Ocean Discovery Program (IODP) Gulf Coast Core Repository. We measured the elemental composition of sediments that encompass planktic foraminiferal Zone E12 from ODP Cores $865 \mathrm{~B}-4 \mathrm{H}$ and $-5 \mathrm{H}$ (27.52-44.58 metres below seafloor, mb.s.f.) and Sections $865 \mathrm{C}-4 \mathrm{H}-1$ to $6 \mathrm{H}-2$ (22.30$42.80 \mathrm{~m}$ b.s.f.) in order to capture overlapping sections and construct a composite splice. We primarily used $\mathrm{Sr} / \mathrm{Ca}$ and $\mathrm{Ba} / \mathrm{Sr}$ ratios determined from the $50 \mathrm{kV}$ scans for splicing purposes. These are unconventional ratios for hole-to-hole correlation, but the low detrital component of the Site 865 sediments necessitated the use of high-intensity elements associated with the carbonate and biogenic barite fractions $(\mathrm{Ca}$, $\mathrm{Sr}$, and $\mathrm{Ba}$ ) for detailed correlation. All XRF elemental data are reported in Table $\mathrm{S} 1$ in the Supplement.

\subsection{Cyclostratigraphy}

To investigate if astronomical forcing drove patterns in the elemental data records, the $\mathrm{Fe}$ intensity data, measured at $30 \mathrm{kV}$, and the natural logarithm of the $\mathrm{Sr} / \mathrm{Ca}$ ratio, $\ln (\mathrm{Sr} / \mathrm{Ca})$, measured at $50 \mathrm{kV}$, were subjected to time series analyses. The $\mathrm{Fe}$ intensity data were selected to allow comparison with published datasets (Westerhold and Röhl, 2013), and the $\ln (\mathrm{Sr} / \mathrm{Ca})$ record was selected for its low signal-to-noise ratio (see Sect. 3.1). The records were evenly sampled and periodicities larger than $7 \mathrm{~m}$ were removed in the program AnalySeries (Paillard et al., 1996). Spectral analyses were performed with Redfit 3.8 (Schulz and Mudelsee, 2002) using a Welch window. The behaviour of periodicities over the length of the dataset was investigated by evolutive harmonic analysis with the astrochron package in R (Meyers, 2014), using window lengths of $5.5 \mathrm{~m}$ for $\ln (\mathrm{Sr} / \mathrm{Ca})$ and $6 \mathrm{~m}$ for $\mathrm{Fe}$ intensity. The Fe record displays a stronger imprint of short-term $(<1 \mathrm{~m})$ variability than the $\ln (\mathrm{Sr} / \mathrm{Ca})$ record. To test whether the observed cycle hierarchy in the Fe record can be confidently linked to an orbital origin, the interval with most persistent periodicities as identified in the evolutive spectrum, between 32.5 and 44.5 "adjusted" metres composite depth (amcd; see below), was investigated with the average spectral misfit (ASM) method in astrochron (Meyers, 2014). Bandpass filters were applied to the datasets centred at periodicities of 1.9 and $50 \mathrm{~cm}$ with broad bandwidths of $1 / 3$ of the centre frequency. The $\ln (\mathrm{Sr} / \mathrm{Ca})$ record displays a stronger imprint of longer $(>1 \mathrm{~m})$ periodicities than the $\mathrm{Fe}$ record, with minima in the $1.9 \mathrm{~m}$ bandpass filter of $\ln (\mathrm{Sr} / \mathrm{Ca})$ generally coinciding with maxima in the $1.9 \mathrm{~m}$ bandpass filter of $\mathrm{Fe}$. High $\mathrm{Fe}$ intensities generally coincide with intervals of higher variability in the Fe record, which are likely controlled by a larger amplitude of variation in the orbital forcing parameters during eccentricity maxima. In concordance with the approach of Westerhold and Röhl (2013), we consider eccentricity maxima to coincide with maxima in the Fe record and, therefore, minima in the $\ln (\mathrm{Sr} / \mathrm{Ca})$ record. A tentative orbital tuning was established by (i) anchoring the maximum in the $1.9 \mathrm{~m}$ bandpass filter of $\ln (\mathrm{Sr} / \mathrm{Ca})$ to the
$405 \mathrm{kyr}$ eccentricity minimum at $40.5 \mathrm{Ma}$ in the La2011 eccentricity solution (Laskar et al., 2011) and (ii) connecting consecutive maxima in the $1.9 \mathrm{~m}$ bandpass filter of $\ln (\mathrm{Sr} / \mathrm{Ca})$ to $405 \mathrm{kyr}$ eccentricity minima. Astronomical tie points are presented in Table S2, and resulting sedimentation rate estimates are in Fig. S2.

\subsection{Planktic foraminiferal and calcareous nannofossil biostratigraphy}

A planktic foraminiferal biostratigraphic scheme, with approximately one sample per core section (every $\sim 1.5 \mathrm{~m}$ ), was previously presented for the middle Eocene of ODP Site 865 (presented in fig. 1 of Pearson and Ezard, 2014). Further analysis of the same sample set, supplemented by new samples available at $10 \mathrm{~cm}$ spacing (as necessary) between Sections 865B-4H-3 and -5H-2, $(\sim 31.20$ $39.98 \mathrm{~m}$ b.s.f.) and between Sections $865 \mathrm{C}-4 \mathrm{H}-1$ and $-6 \mathrm{H}-2$ ( $\sim 22.35-44.05 \mathrm{~m}$ b.s.f.), provided the opportunity to test and refine existing datums. Higher-resolution biostratigraphic analysis also afforded the opportunity to build on previous work to capture both primary bioevents defining planktic foraminiferal zones and key secondary datums as defined by Berggren and Pearson (2005) and Wade et al. (2011). Planktic foraminiferal taxonomy follows Pearson et al. (2006), and species range charts are presented in Tables S3 and S4. Representative specimens of selected biostratigraphically important planktic foraminifera were imaged either under reflected light or using scanning electron microscopy (SEM). Specimens were gold coated prior to SEM analysis, which was conducted on a Philips XL-30 Environmental SEM at the University of Birmingham.

We also define calcareous nannofossil datums (from Martini, 1971; Agnini et al., 2014) based on semi-quantitative counts by Bralower and Mutterlose (1995) at one sample per core section, supplemented with new nannofossil data based on analysis of an additional 20 samples from Sections 865B$4 \mathrm{H}-3$ to $-5 \mathrm{H}-1$ and Sections $865 \mathrm{C}-4 \mathrm{H}-5$ to $-5 \mathrm{H}-5$ (Tables S5 and S6). New calcareous nannofossil data are derived from variable sampling intervals as they were selected to test and refine the published datum events occurring within the focal sampling interval of this study. Calcareous nannofossils were analysed using simple smear slides and standard light microscope techniques (Bown and Young, 1998). Data were collected semi-quantitatively using a Zeiss Axiophot photomicroscope at $\times 1000$ magnification. Species abundance is estimated per field of view (FOV) after viewing at least five slide transects $(>500 \mathrm{FOV})$, with slides studied for at least $40 \mathrm{~min}$. Species range charts are presented in Tables S5 and S6. Taxonomy typically follows Nannotax (Young et al., 2017).

For defining both planktic foraminiferal and calcareous nannofossil datums, we use Top (T) and Base (B) to describe the highest and lowest occurrences of taxa and Top and Base 
common ( $\mathrm{Tc}$ and $\mathrm{Bc}$ ) for the highest and lowest common occurrences, respectively (following Backman et al., 2012).

\subsection{Stable carbon and oxygen isotope measurements}

Benthic foraminiferal stable isotope $\left(\delta^{13} \mathrm{C}\right.$ and $\left.\delta^{18} \mathrm{O}\right)$ data were generated from the epifaunal taxon Nuttallides truempyi following the taxonomic concept of Holbourn et al. (2013). Foraminifers were picked from the 250-300 $\mu \mathrm{m}$ sieve size fraction and cleaned by ultrasonication to remove any loose fine material prior to stable isotope analysis. Benthic foraminifera used for stable isotope analysis were partially recrystallized (with a "frosty" texture) but were not infilled or heavily overgrown (also see Arreguín-Rodríguez et al., 2016). All stable isotope measurements were determined using a Thermo Scientific DELTA V Advantage mass spectrometer coupled to a Gas Bench II in the School of Earth and Ocean Sciences at Cardiff University and are reported relative to the Vienna Pee Dee Belemnite (VPDB) standard. External analytical precision for $\delta^{13} \mathrm{C}$ and $\delta^{18} \mathrm{O}$ analyses is $0.06 \%$ and $0.07 \%$, respectively. No species-specific corrections are applied. Stable isotope data for Holes 865B and $865 \mathrm{C}$ are reported in Tables S7 and S8, respectively.

\section{Results}

\subsection{XRF data and composite splice}

Despite initial concerns about coring disturbance and the lack of clear signals in the shipboard physical property datasets (Shipboard Scientific Party, 1993b), distinct features and cyclicity are evident in the high-resolution XRF records throughout the study interval aiding correlation between holes (Fig. 2; Table S1). Sr/Ca and Ba/Sr ratios are the most useful parameters for correlation because of the higher signal-to-noise ratio compared to other elemental ratios, e.g. $\mathrm{Fe} / \mathrm{Sr}$. For the first time at Site 865 these datasets enabled the identification of several unambiguous tie points between holes and construction of a composite section spanning a $\sim 25 \mathrm{~m}$ interval (Tables 1 and 2). This is the first composite depth scale available for any interval at Site 865 . The biggest difference between the new composite depth scale and the shipboard metres below seafloor (m b.s.f.) depth scale is that the core recovery gap between Cores $865 \mathrm{C}-4 \mathrm{H}$ and $-5 \mathrm{H}$ has increased from $\sim 1$ to $>3 \mathrm{~m}$, requiring significant offsets to be applied. In order to maximize the sample material available for study, out-of-splice intervals were also correlated to the in-splice intervals through development of an "adjusted" metres composite depth (amcd) scale (Tables 3 and 4; Fig. 2). This was achieved by aligning clearly identifiable common features in each hole and defining mapping pairs (Tables 3 and 4) by stretching/squeezing of the out-of-splice core segments to match the in-splice intervals (Fig. 2). All interpretations below are considered relative to the final composite amcd scale. However, the new amcd scale only applies to the
Table 1. Composite depth offsets within splice for ODP Site 865.

\begin{tabular}{llc}
\hline Hole & Core & Splice offset $(\mathrm{m})$ \\
\hline $865 \mathrm{~B}$ & $4 \mathrm{H}$ & 0.78 \\
$865 \mathrm{~B}$ & $5 \mathrm{H}$ & 2.28 \\
\hline $865 \mathrm{C}$ & $4 \mathrm{H}$ & 0.00 \\
$865 \mathrm{C}$ & $5 \mathrm{H}$ & 3.22 \\
$865 \mathrm{C}$ & $6 \mathrm{H}$ & 3.46 \\
\hline
\end{tabular}

intervals for which XRF data were collected, and thus, some of the bioevents reported within this study fall outside of this interval.

\subsection{Cyclostratigraphy}

Spectral analysis of the $\ln (\mathrm{Sr} / \mathrm{Ca})$ record by Redfit displays the most prominent periodicities at 1.9 and $73 \mathrm{~cm}$ and additional periodicities at $3.0 \mathrm{~m}, 2.4 \mathrm{~m}, 78 \mathrm{~cm}$, and $40 \mathrm{~cm}$ above the $95 \%$ confidence level, as well as at $60 \mathrm{~cm}$ above the $90 \%$ confidence level (Fig. 3). In the Fe record, periodicities above the $95 \%$ confidence level are detected at $6.3 \mathrm{~m}$, $1.9-1.2 \mathrm{~m}$, and $63 \mathrm{~cm}$ (Fig. 3), with an additional periodicity of $49 \mathrm{~cm}$ above the $80 \%$ confidence level. Evolutive analyses track the behaviour of the $\sim 1.9 \mathrm{~m}$ and $40-78 \mathrm{~cm}$ periodicities over the length of the record, revealing reduced power at depths around 32.5 and $39.5 \mathrm{amcd}$. ASM analysis of the Fe intensity record from 32.5 to $44.5 \mathrm{~m}$ reveals a hierarchy of periodicities likely corresponding to an orbital imprint at a sedimentation rate of $0.46 \mathrm{~cm} \mathrm{kyr}^{-1}$ (Fig. S2). This is in close agreement with the average sedimentation rate obtained from tuning to the $405 \mathrm{kyr}$ eccentricity cycle at $0.48 \mathrm{~cm} \mathrm{kyr}^{-1}$ on average over the entire record. A sedimentation rate of $0.48 \mathrm{~cm} \mathrm{kyr}^{-1}$ would translate the periodicity of $1.9 \mathrm{~m}$, which is strongly present in the $\ln (\mathrm{Sr} / \mathrm{Ca})$ record, to a duration of $406 \mathrm{kyr}$, which is close to the periodicity of long eccentricity at $405 \mathrm{kyr}$.

\subsection{Planktic foraminiferal biostratigraphy}

All of the samples analysed contain abundant recrystallized or "frosty" planktic foraminifera (see Fig. 4 and Edgar et al., 2015 , for images of wall cross sections). The assemblages are diverse and typical of tropical middle Eocene low-latitude environments (e.g. Pearson et al., 2006; Berggren and Pearson, 2005). The dominant genera are Acarinina, Morozovelloides, Turborotalia, Globigerinatheka, and Subbotina, with minor but conspicuous contributions from Hantkenina, Guembelitrioides, Globanomalina, and Pseudohastigerina. Thus, the (sub)tropical planktic foraminifera zonation scheme of Berggren and Pearson (2005) can easily be applied at this site, and, unusually, a complete sequence of Eocene biomarkers and biozones can be identified. From the pattern of evolutionary bioevents recognized we identify planktic 


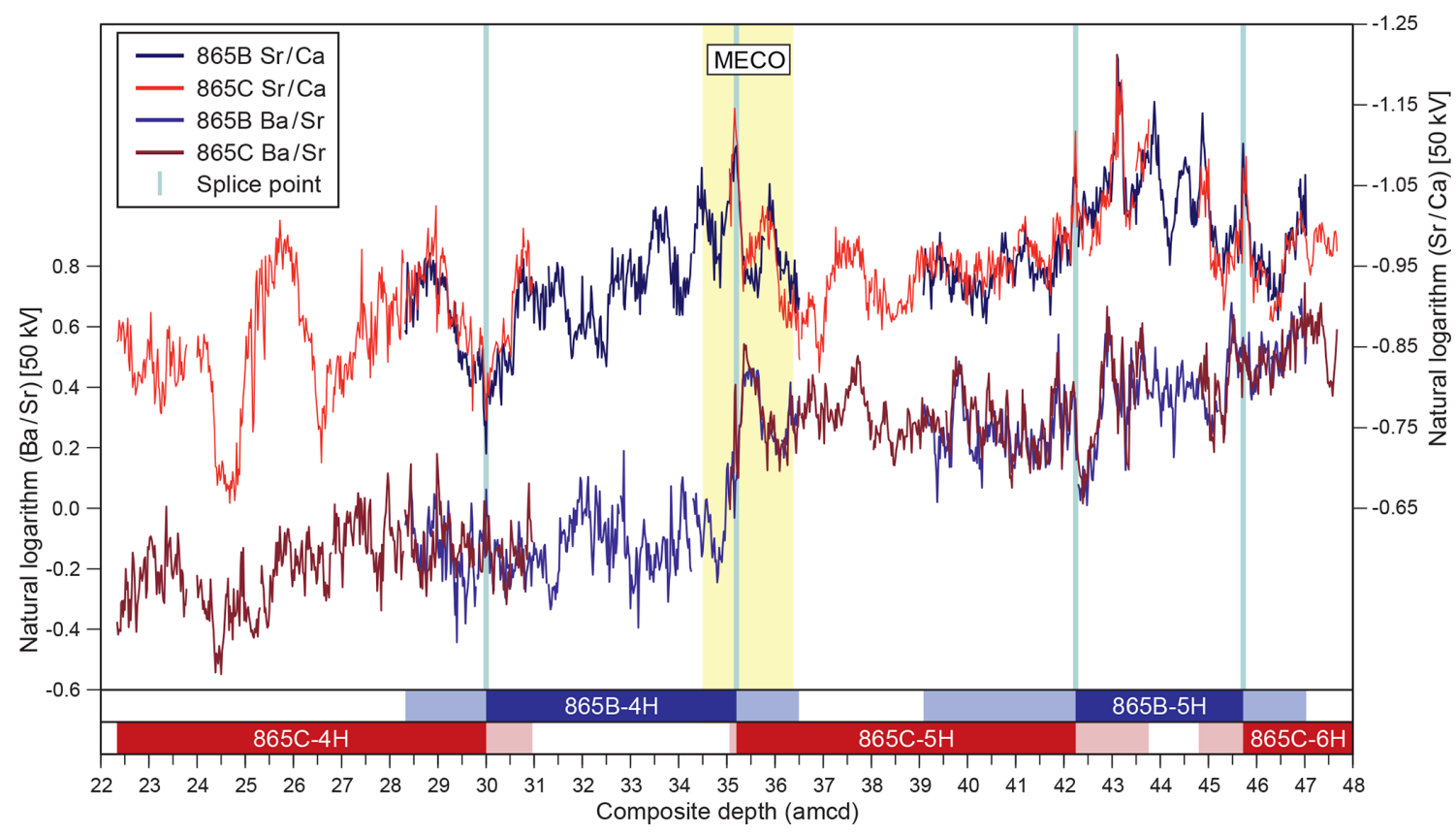

Figure 2. $\mathrm{Sr} / \mathrm{Ca}$ and $\mathrm{Ba} / \mathrm{Sr}$ records derived from XRF core scanning for ODP Holes 865B and 865C on the new adjusted metres composite depth (amcd) scale. Both ratios are calculated from $50 \mathrm{kV}$ scans. Vertical blue lines indicate positions of splice points, and the horizontal bars at bottom of the figure provide a schematic representation of the composite section. Dark shading indicates in-splice intervals of each core, and light shading indicates out-of-splice intervals of each core.

Table 2. Splice tie points for ODP Site 865.

\begin{tabular}{|c|c|c|c|c|c|c|c|c|c|c|c|c|}
\hline $\begin{array}{l}\text { Site, hole, } \\
\text { core, type } \\
\text { section }\end{array}$ & $\begin{array}{r}\text { Interval } \\
(\mathrm{cm})\end{array}$ & $\begin{array}{r}\text { Top of } \\
\text { section } \\
\text { depth } \\
\text { (m b.s.f.) }\end{array}$ & $\begin{array}{r}\text { Depth } \\
\text { (m b.s.f.) }\end{array}$ & $\begin{array}{r}\text { Splice } \\
\text { offset } \\
(\mathrm{m})\end{array}$ & $\begin{array}{l}\text { Depth } \\
\text { (mcd) }\end{array}$ & Correlation & $\begin{array}{r}\text { Site, hole, } \\
\text { core, type } \\
\text { section }\end{array}$ & $\begin{array}{r}\text { Interval } \\
(\mathrm{cm})\end{array}$ & $\begin{array}{r}\text { Top of } \\
\text { section } \\
\text { depth } \\
\text { (m b.s.f.) }\end{array}$ & $\begin{array}{r}\text { Depth } \\
\text { (m b.s.f.) }\end{array}$ & $\begin{array}{r}\text { Splice } \\
\text { offset } \\
(\mathrm{m})\end{array}$ & $\begin{array}{l}\text { Depth } \\
\text { (mcd) }\end{array}$ \\
\hline & & & & & & start $\Rightarrow$ & $865 \mathrm{C}-4 \mathrm{H}-1$ & 4 & 22.30 & 22.34 & 0.00 & 22.34 \\
\hline $865 \mathrm{C}-4 \mathrm{H}-6$ & 20 & 29.80 & 30.00 & 0.00 & 30.00 & tie to & $865 \mathrm{~B}-4 \mathrm{H}-2$ & 22 & 29.00 & 29.22 & 0.78 & 30.00 \\
\hline 865B-4H-5 & 92 & 33.50 & 34.42 & 0.78 & 35.20 & tie to & $865 \mathrm{C}-5 \mathrm{H}-1$ & 18 & 31.80 & 31.98 & 3.22 & 35.20 \\
\hline $865 \mathrm{C}-5 \mathrm{H}-5$ & 122 & 37.80 & 39.02 & 3.22 & 42.24 & tie to & $865 \mathrm{~B}-5 \mathrm{H}-2$ & 146 & 38.50 & 39.96 & 2.28 & 42.24 \\
\hline $865 \mathrm{~B}-5 \mathrm{H}-5$ & 44 & 43.00 & 43.44 & 2.28 & 45.72 & tie to & $865 \mathrm{C}-6 \mathrm{H}-1$ & 96 & 41.30 & 42.26 & 3.46 & 45.72 \\
\hline $865 \mathrm{C}-6 \mathrm{H}-2$ & 141 & 42.80 & 44.21 & 3.46 & 47.67 & $\Leftarrow$ end & & & & & & \\
\hline
\end{tabular}

foraminiferal Zones E10-E15 within the study interval (Table 5; Figs. 5-6). Images of planktic foraminiferal species of biostratigraphic significance are shown in Fig. 4.

The planktic foraminiferal (and calcareous nannofossils, Sect. 3.4) biostratigraphic data serve two purposes: (i) comparison of bioevents in Holes $865 \mathrm{~B}$ and $865 \mathrm{C}$ to provide a check on XRF-based hole-to-hole correlations and (ii) critical age control for this site. The relative sequence and depths of planktic foraminiferal datums in Holes 865B and 865C are in relatively good agreement with one another on the new amcd scale, indicating no major misalignments based on the XRF correlations. The Top of Globigerinatheka semiinvoluta, defining the base of Zone E15, falls in samples outside of the new splice (Table 5), occurring at $20.35 \pm 0.10 \mathrm{~m}$ b.s.f. in Hole $865 \mathrm{~B}$ and at $21.57 \pm 0.80 \mathrm{~m}$ b.s.f. in Hole $865 \mathrm{C}$ (and above 22.37 amcd). Small offsets between the two holes sup- port the minimal composite depth offsets in the uppermost cores $(<0.78 \mathrm{~m}$; Tables 1, 2, and 5; Fig. S2).

Reworking of older into younger material is evident in the upper part of the study section investigated here (above 31 amcd; Fig. 5). Specifically early middle Eocene material is reworked into middle and late Eocene sediments (Tables S3 and S4). The most noticeable example of this is in the overlapping occurrences of $G$. semiinvoluta with the large Acarinina (e.g. A. praetopilensis and A. mcgowrani) and Morozovelloides (M. crassatus and M. lehneri), and even Morozovella aragonensis (from Zones E5-9) in Sections 865C$4 \mathrm{H}-1$ to $-4 \mathrm{H}-4$ and in Sections $865 \mathrm{~B}-3 \mathrm{H}-5$ and $-3 \mathrm{H}-6$. Fortunately reworked specimens are relatively easy to discern as they typically have a distinctive brown/orange stain, may contain small flecks of pyrite, and/or are more poorly preserved, e.g. fragmented. We only find one Plio-Pleistocene 

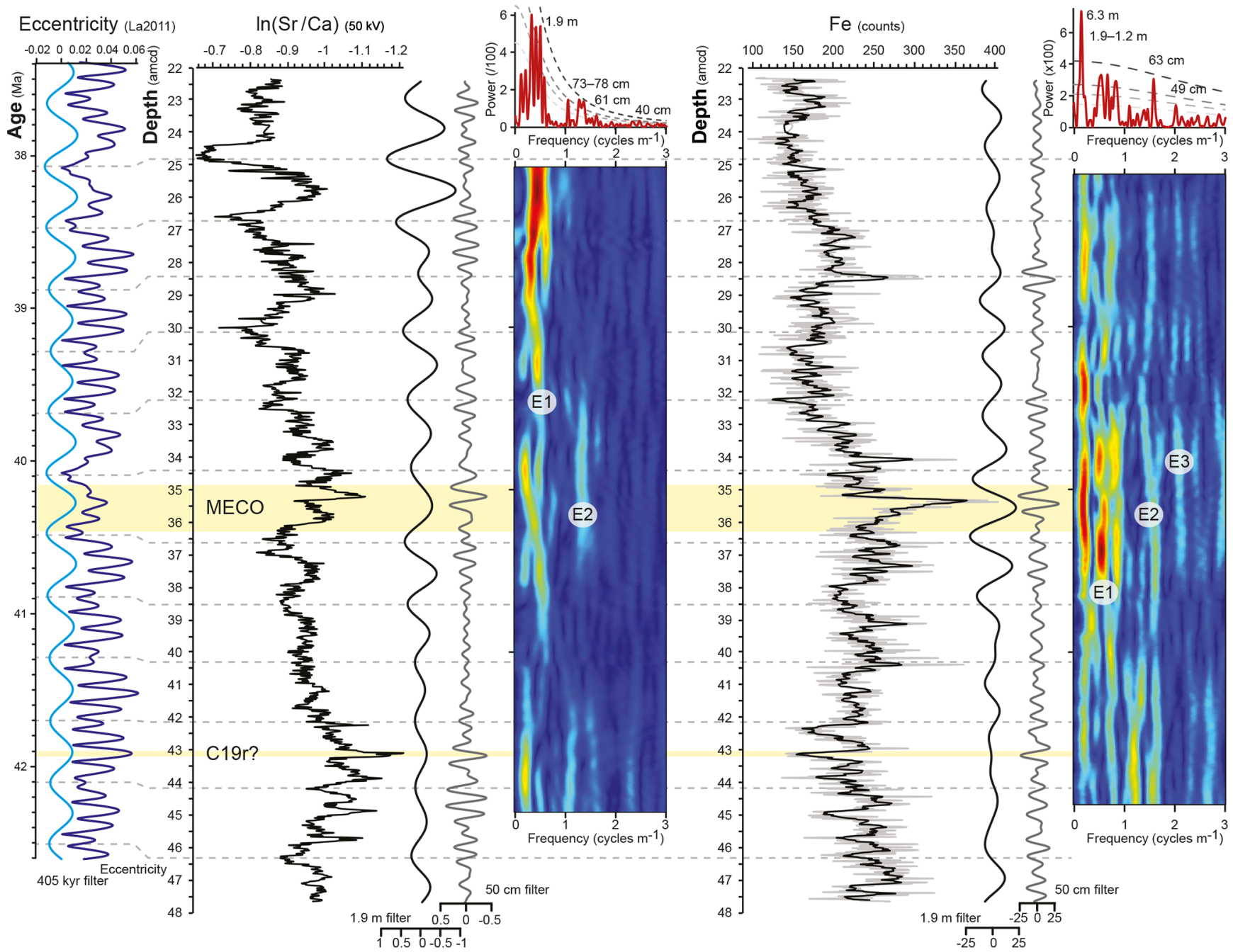

Figure 3. Time series analyses of the $\ln (\mathrm{Sr} / \mathrm{Ca})$ and $\mathrm{Fe}$ intensity data and preliminary orbital tuning. From left to right: the La2011 eccentricity solution (dark blue) and its $405 \mathrm{kyr}$ bandpass filter (light blue) and the $\ln (\mathrm{Sr} / \mathrm{Ca})$ record and the $\mathrm{Fe}$ intensity record, flanked by their $1.9 \mathrm{~m}$ (black) and $50 \mathrm{~cm}$ (grey) bandpass filters and evolutive power spectra, with E1, E2, and E3 indicating the potential imprint of the 405, 125, and $95 \mathrm{kyr}$ components of eccentricity, respectively. The evolutive spectra are topped by Redfit power spectra with dashed lines showing the $99 \%, 95 \%, 90 \%$, and $80 \%$ confidence levels and with main periodicities indicated. Horizontal yellow bands indicate the position of the MECO and the C19r event. Horizontal grey dashed lines indicate tentative tuning tie points between the $\ln (\mathrm{Sr} / \mathrm{Ca}) \operatorname{bandpass}$ filter and the astronomical solution.

species (Globorotalia tumida) indicative of possible downhole contamination in Section 865C-4H-1.

Conspicuous reworking has several consequences for the biostratigraphic zonation in the study interval. First, the Top of $M$. crassatus used to define the base of Zone E14 was not confidently identified here because significant numbers of individuals are present in both Cores $865 \mathrm{~B}-3 \mathrm{H}$ and $865 \mathrm{C}$ $3 \mathrm{H}$. Thus, the Base of G. semiinvoluta, which is calibrated to the same age as the Top of $M$. crassatus was instead used to approximate the base of Zone E14 (27.82 $\pm 0.10 \mathrm{~m}$ b.s.f. in Hole $865 \mathrm{~B}$ and $26.34 \pm 0.07$ amcd in Hole $865 \mathrm{C}$; Table 5). The slight difference between the two horizons may reflect the relative rarity of G. semiinvoluta and difficulty in distin- guishing this taxon from its immediate ancestor Globigerinatheka mexicana at the base of its range (Premoli Silva et al., 2006) and/or that Core 865B-3H falls outside of the new amcd scale. In contrast, the Top of $O$. beckmanni is an easily identifiable datum that defines the base of Zone E13 and is well constrained in Hole 865B (32.14 $\pm 0.06 \mathrm{amcd}$; Table 5). This datum, however, falls in the core gap between Cores $865 \mathrm{C}-4 \mathrm{H}$ and $-5 \mathrm{H}$, and hence there is a large depth uncertainty for this datum in Hole $865 \mathrm{C}(33.00 \pm 2.10$ amcd in Hole 865C; Table 5; Fig. 5). The Base of O. beckmanni, used to define the base of Zone E12, is more difficult to determine because there is a continuous chronocline from its immediate ancestor Globigerinatheka euganea, and thus, 


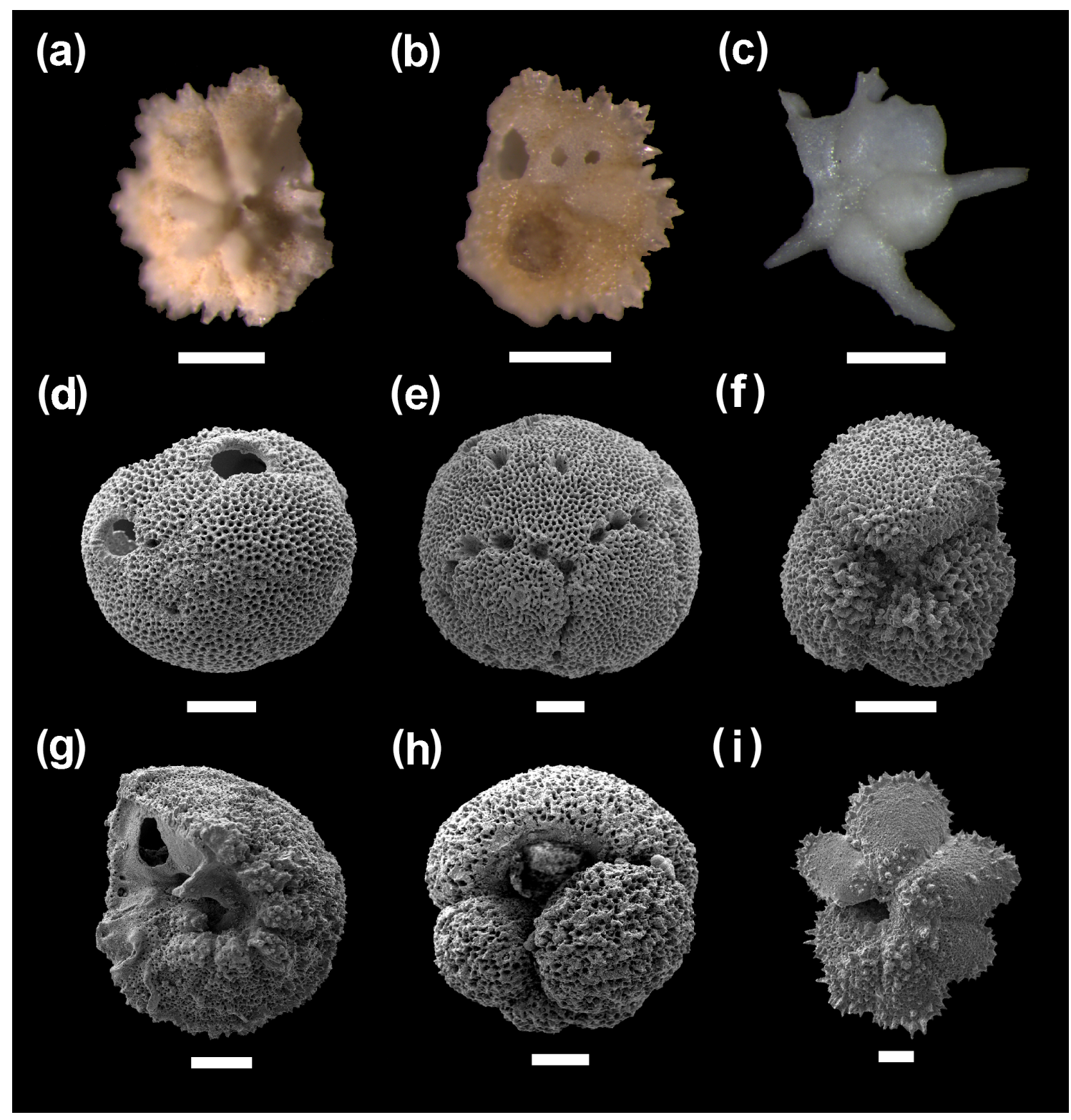

Figure 4. Scanning electron and light microscope images of biostratigraphically important taxa at ODP Site 865. (a, b) Sample ODP Hole 865C-4H-2, 25-27 cm, Morozovelloides lehneri - reworked specimens with distinctive brown/orange discolouration. (c) Sample ODP Hole 865B-6H-1, 73-75 cm, Hantkenina australis. (d) Sample ODP Hole 865C-4H-2, 85-87 cm, Globigerinatheka semiinvoluta, broken final chamber. (e) Sample ODP Hole 865C-5H-1, 5-7 cm, Orbulinoides beckmanni. (f) Sample ODP Hole 865C-5H-4, 85-87 cm, Acarinina bullbrooki. (g) Sample ODP Hole 865C-4H-3, 95-97 cm, a reworked Morozovella aragonensis. (h) Sample ODP Hole 865C-5H-2, 45-47 cm, Globigerinatheka index. (i) Sample ODP Hole 865C-5H-2, 45-47 cm, Morozovelloides lehneri. All scale bars are $100 \mu \mathrm{m}$.

there is no simple morphological discrimination for "early" O. beckmanni forms (Premoli Silva et al., 2006; Edgar et al., 2010). Here we distinguished $O$. beckmanni from $G$. euganea by the presence of a large, hemispherical final chamber with more than four small and often irregular supplementary apertures at its base, multiple supplementary apertures between the chambers in the early whorl (sometimes poorly developed), and if present, areal apertures in the final chamber (areal apertures are not known in G. euganea) (Edgar et al., 2010; Premoli Silva et al., 2006). However, notably, here we find highly developed spherical forms (i.e. with welldeveloped spiral sutural apertures, areal apertures, and $>4$ supplementary apertures at the base of the final chamber) in the lowermost part of the species range at $40.89 \pm 0.07 \mathrm{amcd}$ and $41.03 \pm 0.05$ amcd in Holes $865 \mathrm{~B}$ and $865 \mathrm{C}$, respectively (Table 5). The Top of $A$. bullbrooki occurs $\sim 4 \mathrm{~m}$ above the first occurrence of $O$. beckmanni at both sites $(36.30 \pm 0.06$ in Hole $865 \mathrm{~B}$ and $37.13 \pm 0.05$ amcd in Hole $865 \mathrm{C}$; Table 5) 


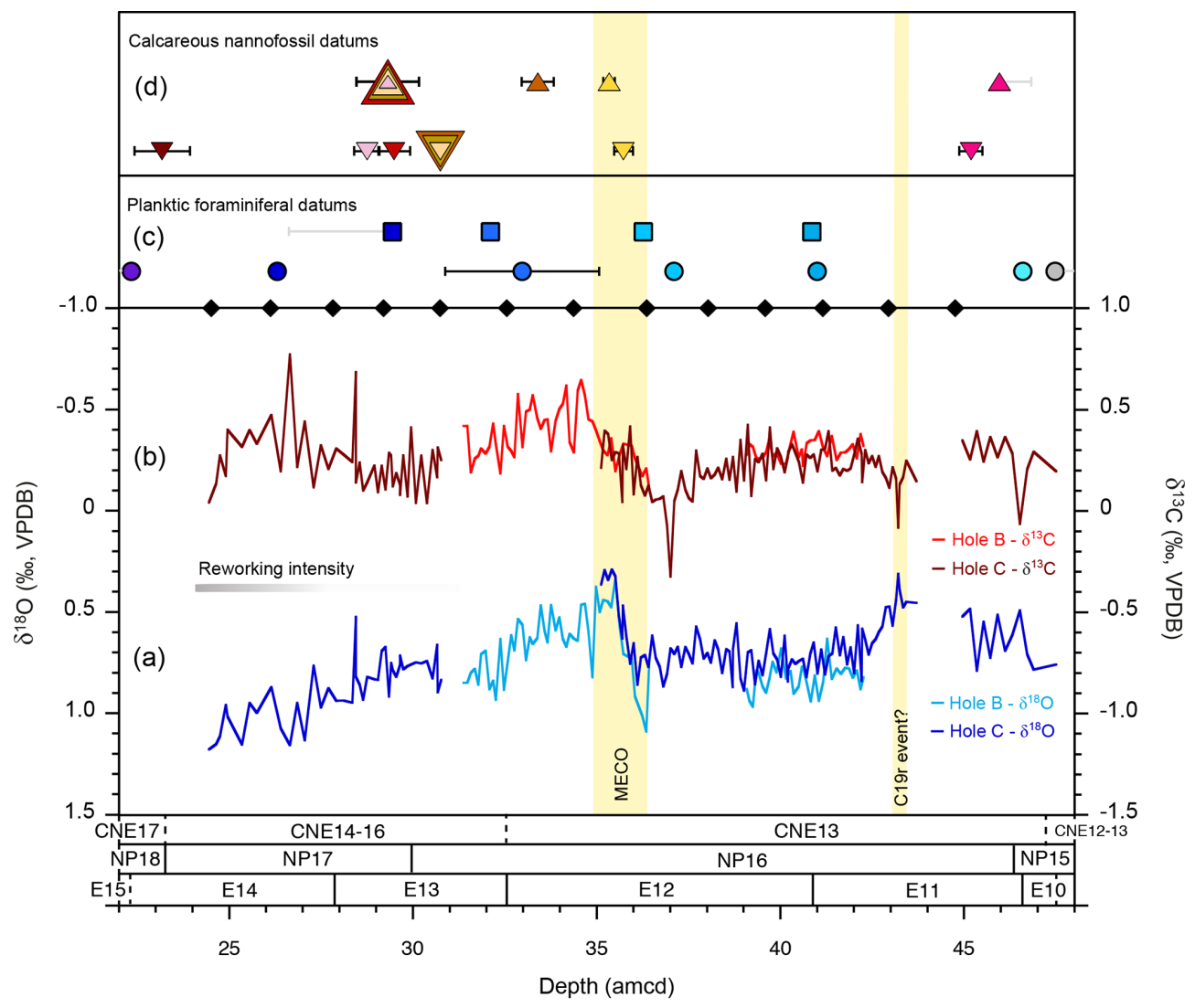

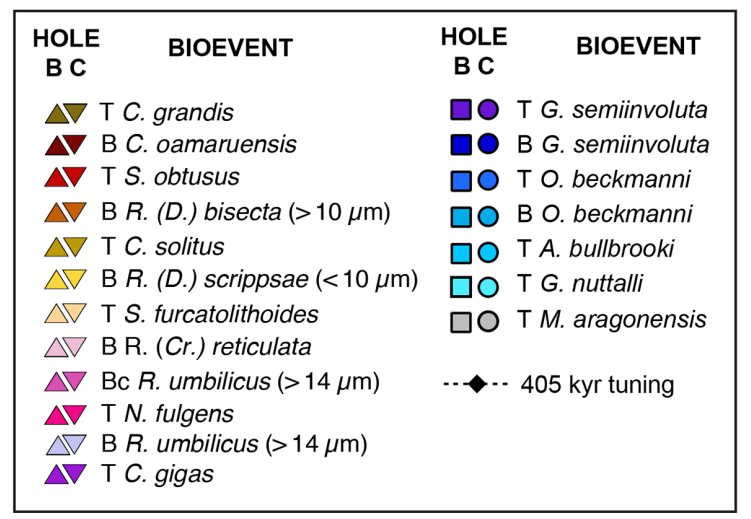

Figure 5. Benthic foraminiferal stable isotope records and age control points in ODP Holes $865 \mathrm{~B}$ and $865 \mathrm{C} .(\mathbf{a}, \mathbf{b}) \delta^{18} \mathrm{O}$ and $\delta^{13} \mathrm{C}$ values are from multi-specimen analyses of Nuttallides truempyi (no vital effect correction has been applied). Gaps in the records represent intervals where no data were generated. (c) Planktic foraminiferal datums are from this study (Table 5). (d) Calcareous nannofossil biostratigraphic markers are from Bralower and Mutterlose (1995) with new data here (Table 6). Depth uncertainties in datums are indicated by vertical lines (black lines: amcd scale; grey line: Top or Bottom depth falls outside of amcd scale and is shown in m b.s.f.) and where not visible are smaller than the symbol. The vertical yellow bars define the positions of the Middle Eocene Climatic Optimum (MECO) and the possible C19r event. T: Top; B: Base; Bc: Base of common occurrence. Note that only datums that fall within the new amcd scale are shown here.

with highly quadrate $A$. bullbrooki forms (Berggren et al., 2006) present that are not obviously reworked. This provides an additional correlative horizon and a check on the correlation between Holes 865B and 865C. Whilst not official biozone markers for this interval of the Eocene, the Hantkenina assemblage at this site is very well developed, and these taxa may be useful accessory markers (Coxall and Pearson, 2006). For instance, we note that Hantkenina australis appears in samples at $\sim 43$ amcd coincident with a pronounced isotopic excursion, which may be correlative with the $\mathrm{C} 19 \mathrm{r}$ event (Fig. 5). 


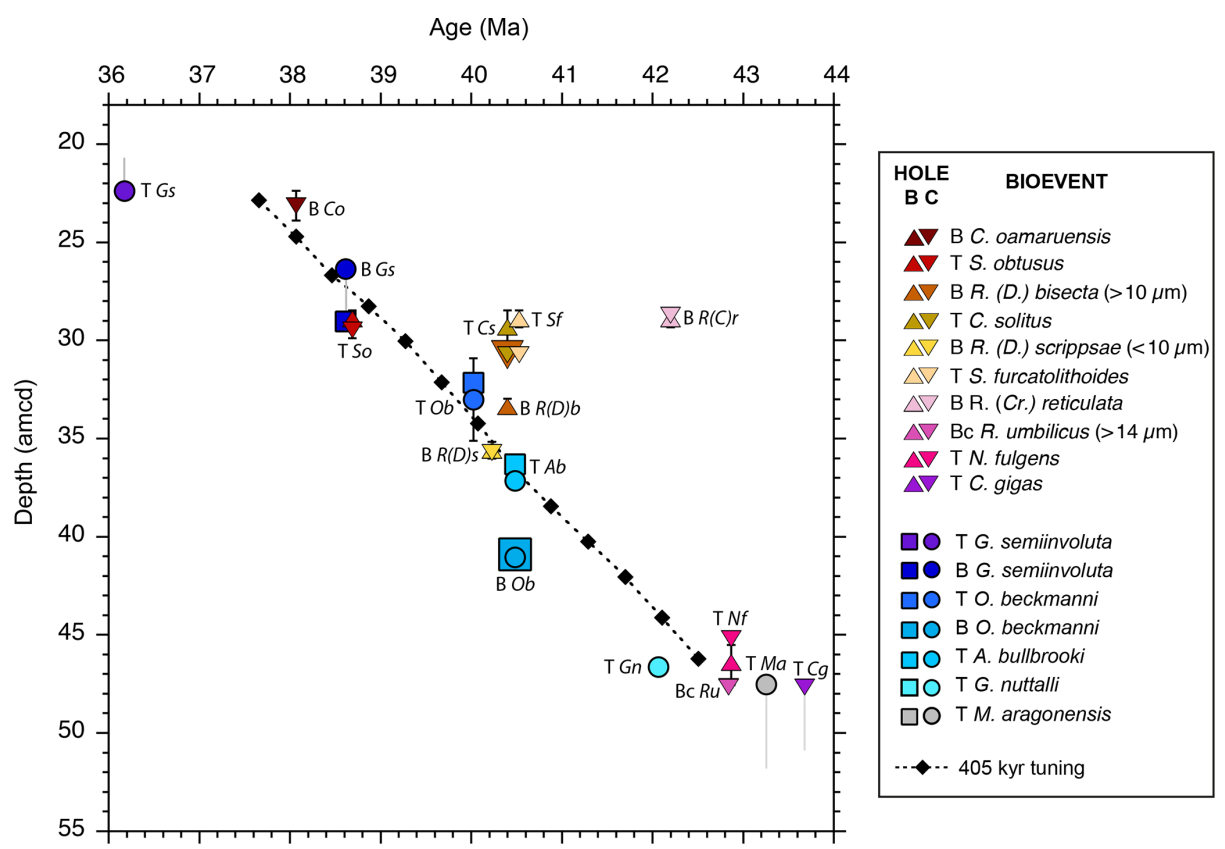

Figure 6. Age-depth plot for ODP Site 865. Only datums falling within the new adjusted metres composite depth (amcd: adjusted metres composite depth) scale are included here. To see all calcareous microfossil datums from the study interval see Fig. S3. Planktic foraminiferal datums are from this study and Pearson and Coxall unpub. (presented in Pearson and Ezard, 2014) (Table 5). Calcareous nannofossil datums are from this study and Bralower and Mutterlose (1995) (Table 6). Depth uncertainties in datums are indicated by vertical lines (black lines: amcd scale; grey line: Top or Bottom depth falls outside of amcd scale and is shown in m b.s.f.) and where not visible are smaller than the symbol. Black diamonds are the tuning tie points to the orbital solution (Table S2). Ages are shown on the Gradstein et al. (2012) timescale. Abbreviations of datums are T, B, or Bc for Top, Base, or Base of common occurrence, respectively, followed by the first letter of the genus and species name.

Table 3. Mapping pairs for adjusting med to amcd for ODP Hole 865B.

\begin{tabular}{lrr}
\hline Site core type & Depth (mcd) & Offset depth (amcd) \\
\hline $865 \mathrm{~B}-4 \mathrm{H}$ & 28.40 & 28.44 \\
$865 \mathrm{~B}-4 \mathrm{H}$ & 28.90 & 29.02 \\
$865 \mathrm{~B}-4 \mathrm{H}$ & 30.00 & 30.00 \\
$865 \mathrm{~B}-4 \mathrm{H}$ & 35.20 & 35.20 \\
$865 \mathrm{~B}-4 \mathrm{H}$ & 36.21 & 36.32 \\
$865 \mathrm{~B}-5 \mathrm{H}$ & 40.12 & 39.82 \\
$865 \mathrm{~B}-5 \mathrm{H}$ & 40.50 & 40.30 \\
$865 \mathrm{~B}-5 \mathrm{H}$ & 41.32 & 41.20 \\
$865 \mathrm{~B}-5 \mathrm{H}$ & 41.74 & 41.72 \\
$865 \mathrm{~B}-5 \mathrm{H}$ & 42.24 & 42.24 \\
$865 \mathrm{~B}-5 \mathrm{H}$ & 45.72 & 45.72 \\
$865 \mathrm{~B}-5 \mathrm{H}$ & 46.80 & 46.81 \\
\hline
\end{tabular}

The lower portion of the Site 865 study interval is assigned to Zones E10 and E11. The Top of Guembelitrioides nuttalli, which defines the base of Zone E11, occurs at $46.62 \pm 0.10$ amcd in Hole $865 \mathrm{C}$ but was not defined in Hole 865B (as it fell outside of the available sample set; Table 5). Notably, a small number of individuals that share the morphology of G. nuttalli with the distinctive high spire, globu-
Table 4. Mapping pairs for adjusting mcd to amcd for ODP Hole $865 \mathrm{C}$.

\begin{tabular}{lrr}
\hline Site core type & Depth (mcd) & Offset depth (amcd) \\
\hline $865 \mathrm{C}-4 \mathrm{H}$ & 22.30 & 22.30 \\
$865 \mathrm{C}-4 \mathrm{H}$ & 30.00 & 30.00 \\
$865 \mathrm{C}-4 \mathrm{H}$ & 30.42 & 30.64 \\
$865 \mathrm{C}-5 \mathrm{H}$ & 35.20 & 35.20 \\
$865 \mathrm{C}-5 \mathrm{H}$ & 42.24 & 42.24 \\
$865 \mathrm{C}-5 \mathrm{H}$ & 43.84 & 43.74 \\
$865 \mathrm{C}-6 \mathrm{H}$ & 45.06 & 45.12 \\
$865 \mathrm{C}-6 \mathrm{H}$ & 45.72 & 45.72 \\
$865 \mathrm{C}-6 \mathrm{H}$ & 47.67 & 47.67 \\
\hline
\end{tabular}

lar chambers, and a pronounced rim (Olsson et al., 2006) but lack supplementary apertures on the spiral side are present sporadically much higher in the site up to $\sim 22$ amcd. The extinction of the distinctive taxon Morozovella aragonensis defining the base of Zone E10 falls outside of the new splice at $48.01 \pm 0.76$ and $47.99 \pm 3.94$ m b.s.f. in Holes $865 \mathrm{~B}$ and $865 \mathrm{C}$, respectively (Table 5). In Hole $865 \mathrm{C}$, this corresponds to the extinction occurring below $47.51 \mathrm{amcd}$. The base of the secondary marker species Globigerinatheka index occurs at $62.10 \pm 0.50 \mathrm{~m}$ b.s.f. in Hole 865B, and the bases of $G$. index 


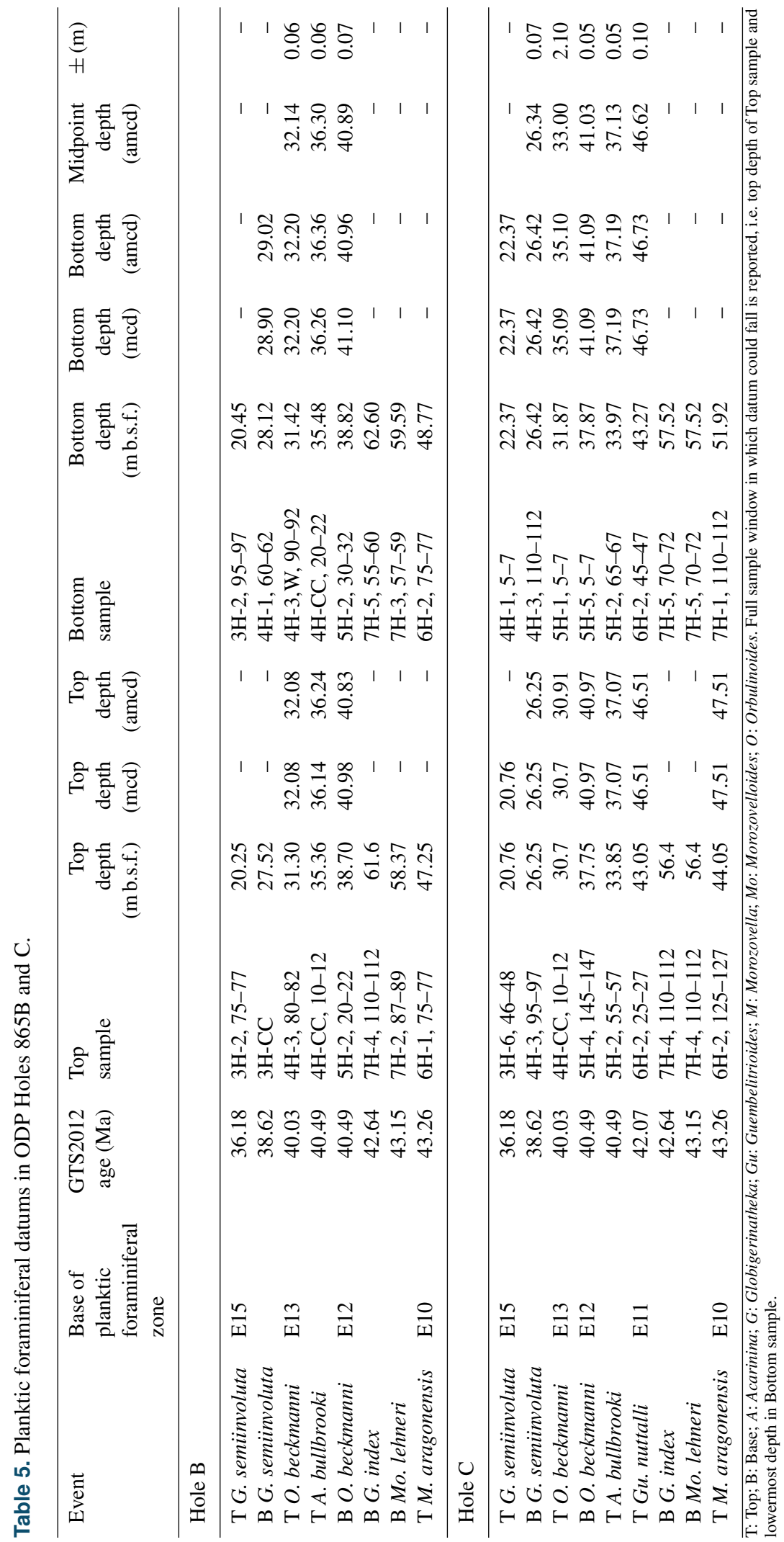


and M. lehneri occur at $56.96 \pm 0.56 \mathrm{~m}$ b.s.f. in Hole $865 \mathrm{C}$ (Table 5). These datums typically occur in Zone E10 but occur well below the Top of $M$. aragonensis here and therefore are within Zone E9.

\subsection{Calcareous nannofossil biostratigraphy}

Calcareous nannofossils at Site 865 are moderately well preserved, showing signs of etching and/or recrystallization, but most specimens are identifiable to species level throughout. Biostratigraphically important calcareous nannofossil occurrences from Bralower and Mutterlose (1995) that fall within our study interval are collated here and where possible translated onto the new amcd scale (Tables 6, S5 and S6). Marker species in Holes 865B and 865C on the new amcd scale are in broad agreement with one another; i.e. datums in both holes overlap or are close to one another in depth space (Fig. 6). Datums that do not quite overlap in terms of depth space include the following: Nannotetrina fulgens, Reticulofenestra (Dictyococcites) bisecta $(>10 \mu \mathrm{m})$, Chiasmolithus solitus, and Sphenolithus furcatolithoides. These inconsistencies are likely a function of the relative rarity of these taxa within the cores making it difficult to reliably determine the highest or lowest true occurrence and/or in some cases this may be exacerbated by etching and overgrowth of some specimens (Bralower and Mutterlose, 1995). However, it is clear from the datums that fall outside of the interval incorporated in the new amcd scale in one or both Holes 865B and 865C (e.g. Bases of Chiasmolithus oamaruensis and Reticulofenestra umbilicus and Top of $C$. gigas and C. grandis; see Fig. S3) that bioevents in Cores $865 \mathrm{~B}-3 \mathrm{H}$ and $865 \mathrm{C}-3 \mathrm{H}$ occur at similar levels, indicating limited offsets between Holes $865 \mathrm{~B}$ and $865 \mathrm{C}$. More significant offsets of up to $5 \mathrm{~m}$ are present between Holes $865 \mathrm{~B}$ and $865 \mathrm{C}$ from Cores $865 \mathrm{~B}-7 \mathrm{H}$ and $865 \mathrm{C}-7 \mathrm{H}$ downwards, indicating that significant adjustments are needed to align the two holes (Table 6).

Consistent with Bralower and Mutterlose (1995), calcareous nannofossil Zones NP15-18 (Martini, 1971) can be clearly identified at Site 865 (Table 6). On the more recent "CNE" zonation scheme (Agnini et al., 2014), the interval encompassing CNE Zones $12-17$ is identified, but Zones CNE14-16 cannot be differentiated. This is because the CNE primary marker species (1) are very rare at this site - Reticulofenestra (Cribrocentrum) erbae; (2) occur in the same narrow window at $\sim 29$ amcd $-\mathrm{T}$ Sphenolithus obtusus and Bc Reticulofenestra (Cribrocentrum) reticulata, defining the bases of Zones CNE16 and 14, respectively (Fig. 6); or (3) appear out of sequence between $\sim 28$ and 32 amcd - e.g. the Bc R. (C). reticulata is very shallow, as are the T S. furcatolithoides, T C. solitus, and B R. (D) bisecta; the last of which also has the largest offsets between the two holes.

\subsection{Benthic foraminiferal stable isotope results}

Benthic foraminiferal stable isotope records in both holes show similar patterns of change and absolute stable isotope values and are well aligned on the new amcd scale (Fig. 5). Benthic foraminiferal $\delta^{18} \mathrm{O}$ values vary between $0.3 \%$ and $1.2 \%$, with minimum $\delta^{18} \mathrm{O}$ values initially recorded at $\sim$ 43 amcd coincident with an abrupt shift of $0.7 \%$ to more negative $\delta^{13} \mathrm{C}$ values. $\delta^{18} \mathrm{O}$ and $\delta^{13} \mathrm{C}$ values subsequently increase and then plateau between 42 and 37 amcd. At $\sim$ $36.5 \mathrm{amcd}$, a second transient negative $\delta^{13} \mathrm{C}$ excursion of $\sim$ $1 \%$ occurs, which is closely followed by a $\sim 0.8 \%$ o shift to lower $\delta^{18} \mathrm{O}$ values at $35 \mathrm{amcd} . \delta^{13} \mathrm{C}$ values increase through this same interval and reach maximum values at 34 amcd. $\delta^{18} \mathrm{O}$ values then gradually increase, and $\delta^{13} \mathrm{C}$ gradually decrease towards the Top of the section at 24 amcd.

\section{Discussion}

\subsection{Reworking}

Reworking of older planktic foraminifera (from Zone P14 now E13) into younger material (Zones E13-E16 and Zone $\mathrm{M} 1$ ) in Cores $865 \mathrm{~B}-1 \mathrm{H}$ to $-3 \mathrm{H}$ was reported during shipboard analysis (Shipboard Scientific Party, 1993b) coinciding with the occurrence of relatively "soupy" sediments with a high water content. A downcore transition to more cohesive sediments coincided with reduced reworking. We demonstrate that reworking of planktic foraminifera extends deeper than this transition but lessens considerably with increasing depth and is not immediately evident below Sections 865B 4H-3 ( $\sim 32.8$ amcd) or $865 \mathrm{C} 4 \mathrm{H}-4$ ( $28.3 \mathrm{amcd}$ ) (Fig. 5). Only discrete time intervals are obviously mixed into younger sediments; i.e. reworked material is sourced from sediments deposited during Zone E13 (as we find reworked Morozovelloides and Acarinina but not $O$. beckmanni from Zone E12) along with much older sediments from Zones E8 to 9 (based on $M$. aragonensis and $G$. nuttalli). Reworking is also present within nannofossil assemblages; for example, rare occurrences of $C$. gigas, Triquetrorhabdulus inversus, and Chiasmolithus consuetus occur up to $15 \mathrm{~m}$ above their highest consistent occurrences in Cores $865 \mathrm{~B}-3 \mathrm{H}$ and $-4 \mathrm{H}$ and for $C$. gigas in Cores $865 \mathrm{C}-3 \mathrm{H}$ and $-4 \mathrm{H}$ (Table 5; Bralower and Mutterlose, 1995). These occurrences are consistent with remobilization of similar-aged sediments and depositional intervals to those identified by planktic foraminifera (Bralower and Mutterlose, 1995). Down-hole contamination was not obvious within planktic foraminifera assemblages but was problematic within calcareous nannofossil samples and was attributed to contamination from the saw used to split the cores and the high water content of the cores (Bralower and Mutterlose, 1995). Benthic foraminiferal assemblages appear relatively unaffected by reworking or downhole contamination (Arreguín-Rodríguez et al., 2016). However, many deep-sea benthic foraminifera species are long-lived making rework- 


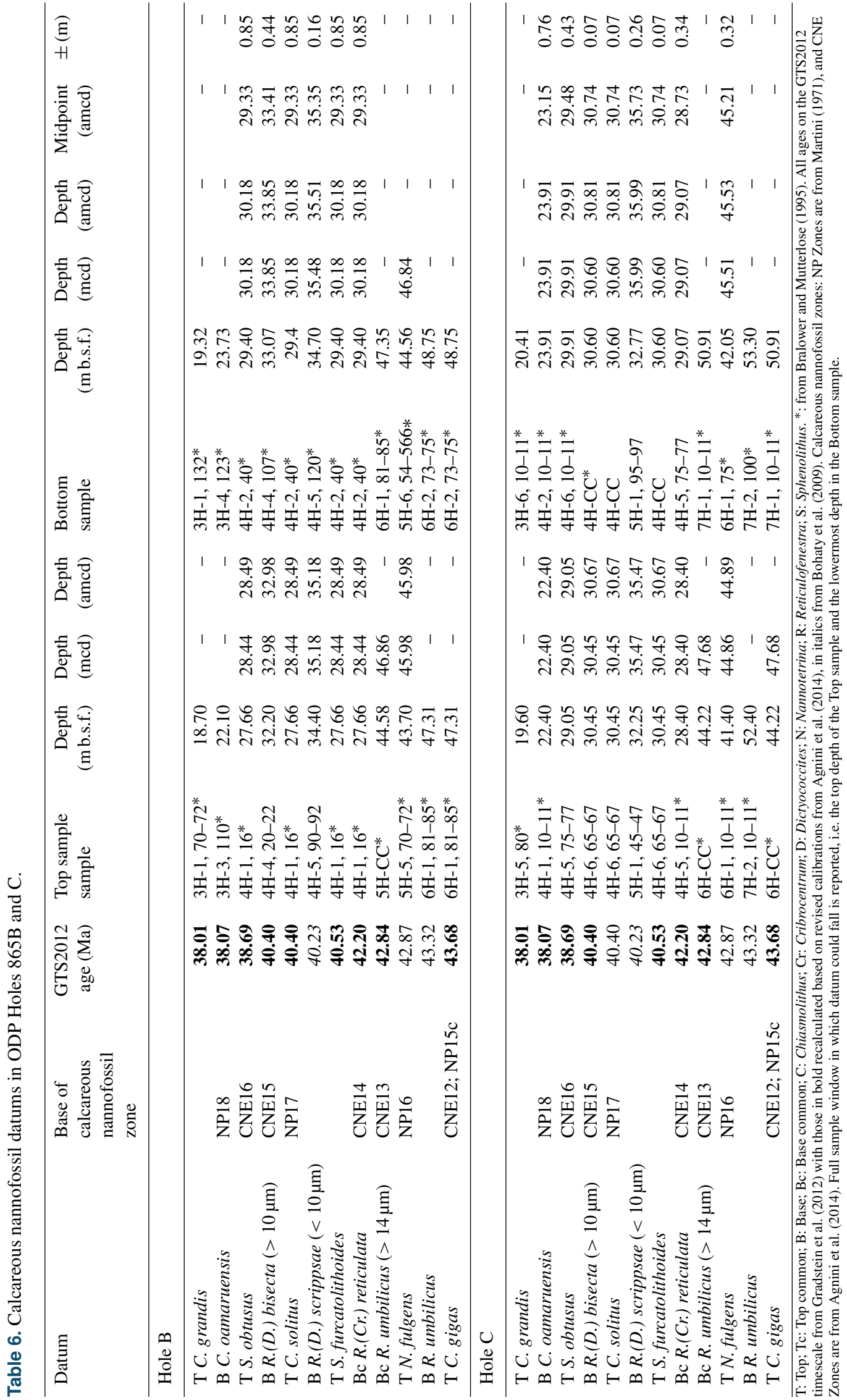


ing difficult to recognize over the short intervals such as those investigated here.

Reworking is very common in the pelagic cap sequences atop guyots drilled during ODP Legs 143 and 144 in the equatorial Pacific, with the most intense reworking reported in the lowermost $\sim 40 \mathrm{~m}$ of pelagic sediments deposited above the drowned carbonate platforms related to changes in local hydrography (Premoli Silva et al., 1993; Pearson, 1995). Less intense reworking is also observed at higher (i.e. younger) levels in pelagic cap sequences and is more limited to discrete horizons and time intervals (Watkins et al., 1995; Pearson, 1995). Reworked material is likely sourced from the edges of the guyot top and transported towards the centre by intensification of bottom-water currents deflected up over the guyot as well as other localized hydrographic features common to these settings, ultimately helping to generate the characteristic low dome-shaped sediment stack found on many Pacific guyots (Genin et al., 1989; Pearson, 1995).

ODP Site 865 sits in an oceanographically dynamic area, relatively close to the edge of the guyot, where the sedimentary cap starts to thin; e.g. it lacks the thick MioceneQuaternary overburden of the guyot centre (Shipboard Scientific Party, 1993b). The abraded appearance of reworked foraminifera (e.g. dull lustre and fragmented) suggests that they have been exposed to intense mechanical erosion, e.g. from currents and/or a more intense transport history than the in situ assemblage (Pilkey et al., 1969; Maiklem, 1967). However, the pervasive brown foraminiferal discolouration on many specimens, an oxidized iron stain and pyrite, likely reflect deposition in a low-sedimentation (and hence high current intensity) area with iron sourced from the contemporaneous formation of manganese-phosphate hardgrounds or remobilized from the lower limestone platform (Shipboard Scientific Party, 1993b). Together these lines of evidence suggest a similar reworking mechanism to that observed on other Pacific guyots (Pearson, 1995; Watkins et al., 1995) with sediments mobilized from the low sedimentation margins of the guyot top during discrete intervals of increased local current intensity and then mixed into sediments closer to the centre of the pelagic cap. Crucially, currents around Site 865 were clearly sufficient to mix and remobilize sediments at times in the late middle Eocene but not to scour the guyot top of sediments. Consistent with this hypothesis is a reduction of sedimentation rates above $\sim 25$ amcd or $25 \mathrm{~m}$ b.s.f. (Figs. 5 and S3) coincident with the zone of most intense reworking. Lower sedimentation rates, in addition to being consistent with elevated current activity either removing sediment or preventing deposition, would also reduce dilution of mixed components in sediments by in situ fauna making the reworking more evident. Regardless of reworking, the ability to correlate the XRF records at the decimetre scale and the coherent stable isotope stratigraphy through Cores $865 \mathrm{~B}-4 \mathrm{H}$ to $-6 \mathrm{H}$ and $865 \mathrm{C}-4 \mathrm{H}$ to $-6 \mathrm{H}(\sim 22$ to 48 amcd $)$ suggests that reworking is relatively easy to avoid (benthic foraminifera were generally better preserved than planktic counterparts, e.g. with no evidence of staining or abrasion), not pervasive throughout the site, and most critically, has not obscured primary environmental signals.

\subsection{Climatic events at ODP Site 865}

The long-term shift towards more positive benthic foraminiferal $\delta^{18} \mathrm{O}$ values observed through the Site 865 study interval (Fig. 5) is consistent with a previously published low-resolution benthic foraminiferal stable isotope record spanning the middle and upper Eocene at this site (Coxall et al., 2000; Bralower et al., 1995), as well as the global Eocene cooling trend (Zachos et al., 2008; Bohaty and Zachos, 2003). Superimposed on this long-term trend is a transient negative $\delta^{18} \mathrm{O}$ excursion of $\sim 0.8 \%$ between $\sim 35-36$ amcd, within calcareous nannofossil and planktic foraminiferal Zones NP16 and E12, respectively, which is identified here as the MECO event (Fig. 5). The onset of the event is defined at the point where $\delta^{18} \mathrm{O}$ begins to show a transition to more negative values. The end of the event is less clearly defined, as at some other sites (Bohaty et al., 2009; Giorgioni et al., 2019; Boscolo Galazzo et al., 2014). However, the distinctive $\delta^{13} \mathrm{C}$ maximum (of $\sim 0.6 \%$ ), which immediately follows the MECO (e.g. Bohaty et al., 2009; Edgar et al., 2010; Spofforth et al., 2010; Boscolo Galazzo et al., 2014; Giorgioni et al., 2019), suggests that the abrupt increase to more positive $\delta^{18} \mathrm{O}$ values at $35 \mathrm{amcd}$ likely marks the end of the event (see vertical yellow bar in Fig. 5). Indeed, the gradual increase to more positive $\delta^{18} \mathrm{O}$ values that follows between $\sim 30-35$ amcd is also seen at multiple ODP sites, including Sites 738, 748, and 1051 where the end of the event is clearly defined (Edgar et al., 2010; Bohaty et al., 2009).

The new composite record constructed using XRF data enables us to capture the entire MECO event at Site 865 . However, very low sedimentation rates $\left(<0.6 \mathrm{~cm} \mathrm{kyr}^{-1}\right.$; Table S2) at this site compared to many other deep-sea sites (Bohaty and Zachos, 2003; Edgar et al., 2010; Boscolo Galazzo et al., 2014) mean that the event is highly condensed and only spans a $\sim 1 \mathrm{~m}$ interval (Fig. 3 ). This is consistent with the reduced magnitude of the $\delta^{18} \mathrm{O}$ excursion ( $\sim 0.8 \%$ vs. $1.0 \% \circ-1.5 \%$ ) compared to elsewhere, the lack of a short $(<50 \mathrm{kyr})$ negative $\delta^{13} \mathrm{C}$ excursion coincident with peak MECO conditions (defined by the $\delta^{18} \mathrm{O}$ minimum), and the rapid apparent onset of the event (Boscolo Galazzo et al., 2014).

Constraining the magnitude, timing, and pattern of CCD change across Eocene global warming events provides vital clues as to the source, mass, and rate of carbon input driving these events. This is particularly true for the MECO, dubbed a "carbon cycle conundrum" (Sluijs et al., 2013), because, over the relatively "long" event duration $(\sim 300-500 \mathrm{kyr})$, increasing atmospheric $\mathrm{CO}_{2}$ levels, and associated warming should have increased weathering rates leading to CCD deepening rather than the observed shoaling (Sluijs et al., 2013; 
Bohaty et al., 2009). Because of its relatively shallow water sedimentation, Site 865 is a critical end-member for constraining the Pacific CCD response during the MECO and other Eocene shoaling events. At $>900 \mathrm{~m}$, the CCD shoaling associated with the MECO is the largest known in the middle-to-late Eocene interval (shoaling from $\sim 4.2 \mathrm{~km}$ to above $3.3 \mathrm{~km}$ palaeo-water depth; Pälike et al., 2012). Relatively continuous carbonate sedimentation across the event at ODP Site 865 suggests that the CCD did not shoal above $\sim 1300-1500 \mathrm{~m}$ (the estimated palaeo-water depth of the site; Shipboard Scientific Party, 1993b) in the Pacific Ocean at this time providing a maximum limit of $3 \mathrm{~km}$ change.

The negative carbon and oxygen isotopic excursions represented here by only a single sample at $\sim 43$ amcd (Fig. 5), in planktic foraminiferal Zone E11, immediately before a shift to more positive $\delta^{18} \mathrm{O}$ values likely corresponds to the "C19r event", a transient hyperthermal-style event $(<$ $100 \mathrm{kyr}$ in duration) initially recognized at ODP Site 1260 in the equatorial Atlantic (Edgar et al., 2007). The C19r event is now also known from the South Atlantic at ODP Sites 1263 and 702 and referred to as the Late Lutetian Thermal Maximum (Westerhold et al., 2018a). Similar to the MECO, the relatively small stable isotope excursions compared to elsewhere $(0.4 \%$ and $0.2 \%$ vs. $1.5 \%$ and $\sim 1.8 \%$, in $\delta^{13} \mathrm{C}$ and $\delta^{18} \mathrm{O}$ at ODP Sites 865 and 1260 , respectively) are likely a function of the low sedimentation rates at this site $\left(\sim 0.4-0.6 \mathrm{~cm} \mathrm{kyr}^{-1}\right.$ vs. $2.0 \mathrm{~cm} \mathrm{kyr}^{-1}$ at ODP Site 1260$)$ compounded by lower sampling frequency and time averaging. This is the first record of the C19r event outside of the Atlantic Ocean and suggests that the C19r event is in fact global in nature and, as such, may be a valuable stratigraphic marker within the long $>1 \mathrm{Myr}$ planktic foraminiferal Zone E11 in which it falls.

A tentative astronomical tuning for the MECO interval of Site 865 based on correlation of the bandpass filter of $\ln (\mathrm{Sr} / \mathrm{Ca})$ to the $405 \mathrm{kyr}$ component of eccentricity, anchoring the record near the onset of the MECO to the eccentricity minimum at $40.5 \mathrm{Ma}$ (Westerhold and Röhl, 2013), is in close agreement with available biostratigraphic age control (Fig. 6). This interpretation places the peak $\delta^{18} \mathrm{O}$ excursion during the MECO within a $405 \mathrm{kyr}$ eccentricity maximum at $40.3 \mathrm{Ma}$, and the carbon-isotope maximum directly following the MECO coincides with the $405 \mathrm{kyr}$ eccentricity minimum at $40.1 \mathrm{Ma}$, in agreement with Westerhold and Röhl (2013). The duration of the interval between the potential C19r event and the onset of the MECO is estimated at three and a half $405 \mathrm{kyr}$ cycles or $1.4 \mathrm{Myr}$, which is longer than the duration estimated by Westerhold and Röhl (2013) at two and a half $405 \mathrm{kyr}$ cycles, $\sim 1 \mathrm{Myr}$. Unfortunately, a detailed comparison to existing cyclostratigraphic studies is hampered by uncertainty in the detection of the C19r event. The apparent differences in these duration estimates are in line with existing discrepancies between astrochronologies, notably in the reported length of magnetochron C19r, with duration estimates varying between $0.9 \mathrm{Myr}$ (Westerhold and
Röhl, 2013; Westerhold et al., 2014, 2015) and $1.5 \mathrm{Myr}$ (Boulila et al., 2018).

\subsection{Integrated biostratigraphic schemes and relationship to the MECO}

Whilst both calcareous nannofossil and planktic foraminiferal zonation schemes can be applied to ODP Site 865 and are in generally good agreement, there is significant disagreement in the post-MECO interval between $\sim 35$ and 30 amcd (Fig. 6). Taken at face value, planktic foraminifera indicate constant sedimentation rates of $\sim 0.5 \mathrm{~cm} \mathrm{kyr}^{-1}$ throughout this interval, whereas calcareous nannofossil datums suggest a $3.5 \mathrm{Myr}$ hiatus between 38.6 and 42.1 Ma. However, XRF-derived elemental and stable isotope datasets and cyclostratigraphic analysis do not indicate any large shifts at this level that might indicate an abrupt shift in environmental conditions (Figs. 2, 3, and 5). The identified presence of the MECO event itself, which falls within this potential gap, also implies that a hiatus is unlikely.

It is instead likely that low sedimentation rates and sampling frequency make it difficult to discern closely spaced calcareous nannofossil bioevents at Site 865, e.g. Tops of C. solitus and S. furcatolithoides, which are calibrated to a $130 \mathrm{kyr}$ interval (40.40-40.53 Ma). However, these events also occur much higher in the section than expected relative to the MECO event at this site, and they also overlap with the much younger Top of $S$. obtusus and Base of $R$. (C.) reticulata (Fig. 5). Explanations could include the following: these bioevents are diachronous and/or are not well calibrated or there is subtle reworking of calcareous nannofossils. As discussed above, this interval does indeed show evidence of reworking (Fig. 3), which could have extended the Tops of species to higher in the section than expected and introduced a degree of subjectivity in determining what is in situ versus reworked. More intense bioturbation and/or higher core water content through this interval may have further affected the datum levels. However, a number of recent studies have questioned the accuracy of long-standing calcareous nannofossil age calibrations (e.g. Agnini et al., 2014; Tori and Monechi, 2013). For instance, many Chiasmolithus bioevents (including $C$. solitus) are no longer included in the most recent calcareous nannofossil zonation scheme because typically low and sporadic abundances of these species at many sites introduces significant uncertainty to reported datum levels (Agnini et al., 2014; Larrasoaña et al., 2008; Villa et al., 2008). We also note differences in the relative positions of the first occurrences of $R$. (D.) bisecta $(<10 \mu \mathrm{m})$ and $R$. (D.) bisecta/scrippsae $(>10 \mu \mathrm{m})$ in multiple studies, but this may also reflect taxonomic problems that are associated with the definition of these taxa (e.g. Mita, 2001; Tori and Monechi, 2013; Larrasoaña et al., 2008; Backman, 1987). The relatively high position of the Base of $R$. (C.) reticulata at Site 865 is also consistent with the highly variable position 
of this event reported from other sites, ranging from magnetochron $\mathrm{C} 20 \mathrm{r}$ to $\mathrm{C} 18 \mathrm{n} .2 \mathrm{n}$ (a $\sim 5 \mathrm{Myr}$ interval; Fornaciari et al., 2010; Rivero-Cuesta et al., 2019; Fioroni et al., 2012). However, given the sporadic and rare presence of $R$. $(C$.) reticulata in our own observations here, the most likely explanation is ecological bias at Site 865. Similarly, N. fulgens is typically rare with an infrequent distribution at Site 865 and elsewhere, reducing its biostratigraphic utility (Bown, 2005; Shamrock, 2010).

The Base of $O$. beckmanni is diachronous, with the species first appearing in the tropics prior to the MECO but subsequently expanding to higher latitudes across the onset of the MECO and inferred surface water warming (Edgar et al., 2010; Luciani et al., 2010; Jovane et al., 2010). At Site 865, the Base of $O$. beckmanni precedes the MECO event, which is consistent with this hypothesis (Fig. 3). The Top of O. beckmanni occurs after the MECO event at Site 865, as at ODP Site 1051 and in the Alano section in the Atlantic and Tethyan oceans, respectively (Luciani et al., 2010; Edgar et al., 2010), suggesting that cooling of surface waters following the MECO was not directly responsible for its extinction. Regardless, planktic foraminiferal Zone E12 is a good marker for the MECO interval in (sub)tropical sediments that lack a stable isotope stratigraphy. The first occurrence of $R$. (D.) scrippsae $(R$. (D.) bisecta $<10 \mu \mathrm{m})$ at low- and midlatitude sites is also used to approximate the beginning of the MECO event based on close correlation at a number of sites in the Atlantic Ocean (Bohaty et al., 2009). The Base of $R$. (D.) bisecta $<10 \mu \mathrm{m}$ does occur within the MECO event at ODP Site 865 (Fig. 5).

The robust and cosmopolitan planktic foraminifera A. bullbrooki is a valuable secondary marker that is approximately coincident with the base of Zone E12 at $40.04 \mathrm{Ma}$ at many sites (Wade et al., 2011; Gradstein et al., 2012) and can be applied when $O$. beckmanni is absent either due to its relatively high susceptibility to mechanical damage and dissolution or limited (sub)tropical distribution (Edgar et al., 2010). However, here we find that the Top of A. bullbrooki and the Base of $O$. beckmanni are not synchronous as implied by the current biozonation scheme (Wade et al., 2011). Whilst there can be a degree of subjectivity in the definition of $O$. beckmanni between workers at the start of its range (Premoli Silva et al., 2006) this is not the case at ODP Site 865 where highly spherical and distinctive forms are present in the lowermost samples (assuming that downhole contamination is not a major, issue; Fig. 4). There are relatively few sites where both taxa are reported but at ODP Sites 1051 and 1260, in the (sub)tropical Atlantic Ocean, the Top of A. bullbrooki also occurs significantly higher than the Base of $O$. beckmanni before (Site 1051) or even after (Site 1260) the MECO event (Shipboard Scientific Party, 2004, 1998; Edgar et al., 2010). In the Contessa section, Italy, the Top of $A$. bullbrooki occurs significantly below the Base of $O$. beckmanni and the MECO (Jovane et al., 2010). Either way, the events are not contem- poraneous, suggesting that a significant revision of this datum is required.

Whilst Hantkenina is present in low abundance throughout the middle-to-upper Eocene section of Site 865 (Coxall et al., 2000), there is a transient appearance of rare Hantkenina australis, a distinctive middle Eocene form with recurved tubulospines, within the inferred C19r "hyperthermal" event. This is surprising because this taxon is found globally, but, unlike most other Hantkenina spp., is most abundant at higher latitudes and, thus, in cooler waters (Coxall and Pearson, 2006). The appearance of Hantkenina australis may prove to be a future useful biostratigraphic marker for C19r, within an otherwise "datum-poor" interval. Notably, previous transient incursions of more tropical species of Hantkenina to high northern latitudes $\left(>50^{\circ} \mathrm{N}\right)$ in the middle Eocene at ODP Site 647 have previously been used to infer surface ocean warming around the C19r interval (Shipboard Scientific Party, 1987). However, stratigraphic revision of ODP Site 647 by Firth et al. (2012) places the lower Hantkenina incursion at the base of calcareous nannofossil Zone NP16 and close to the magnetochron $18 \mathrm{r} / 19 \mathrm{n}$ boundary, which is significantly later than the $\mathrm{C} 19 \mathrm{r}$ event but before the MECO - and inconsistent with the hypothesis of expansion of the Hantkenina range in response to warming surface waters. Thus, these incursions may instead reflect changes in upwelling or increased primary production (Coxall et al., 2007).

The Top of G. nuttalli was introduced as the marker for the base of planktic foraminiferal Zone E11 in 2005, based on correlations at ODP Sites 1050 and 1051 (R. D. Norris, personal communication, cited in Berggren and Pearson, 2005) to break up the otherwise very long multi-million-year Zone P12 from the earlier zonation scheme (Berggren et al., 1995). However, occurrences of $G$. nuttalli (albeit small individuals) have now been found as high as Zone E14 (i.e. above the MECO) in the Alano section in northern Italy, with the highest consistent occurrence in Zone E13 (Agnini et al., 2011). The datum level reported in Table 5 ( $46.62 \pm 0.10$ amcd) is the highest consistent occurrence of this taxon at Site 865, but, similar to Alano, we find at least sporadic occurrences of small individuals up through Zones E13 and E14 that are not obviously reworked.

A number of bioevents within Zone E10 at Site 865 are out of sequence with respect to the primary datum - the Top of $M$. aragonensis $(43.26 \mathrm{Ma}$ ) - occurring above the Bases of younger taxa G. index and M. lehneri (at 42.64 and $43.15 \mathrm{Ma}$, respectively). It is the highest occurrences of taxa that are most likely to be impacted by reworking. Yet $M$. aragonensis specimens do not show distinctive staining or worn appearance at this level (as they do higher up in Hole $865 \mathrm{C}$ where they are clearly reworked), and, whilst individuals could be remobilized locally, a higher Top of $M$. aragonensis compared to G. index is also evident in the Contessa section, Italy (Jovane et al., 2010).

Clearly more work is needed to confidently understand the relative patterns of calcareous nannofossil and planktic 
foraminiferal datums in the middle Eocene. This is particularly true for the Pacific Ocean since most (if not all) calibrations are currently based on Atlantic or Tethyan sediment sequences and indeed few sites where both groups are intercalibrated (e.g. Agnini et al., 2014; Berggren and Pearson, 2005). Whilst many key tropical middle Eocene bioevents are identified at Site 865, the lack of magnetic or confident astrochronology hinders determination of the absolute age of the events reported here. However, in the future, the highresolution stable isotope and XRF records should enable the development of a more robust orbitally tuned age model here or allow correlation to sites elsewhere that possess an independent reliable stratigraphy.

\section{Conclusions}

In this study, we have developed new biostratigraphic, stable isotope, and XRF records that span the MECO event at ODP Site 865 in the tropical Pacific Ocean. This site possesses a surprisingly coherent signal in XRF-derived elemental counts and ratios permitting us to construct a reliable composite section for Holes $865 \mathrm{~B}$ and $865 \mathrm{C}$ spanning the late middle Eocene time interval $(\sim 38-43 \mathrm{Ma})$. Cyclicity observed in XRF datasets is likely orbitally paced, and a tentative astronomical tuning of the study section indicates consistently low but steady sedimentation rates of $\sim 0.4-0.6 \mathrm{~cm} \mathrm{kyr}^{-1}$, in agreement with bio- and chemostratigraphic age calibrations and correlations to other sites. Benthic foraminiferal stable isotope data indicate that the MECO and the C19r events are present at Site 865, albeit relatively condensed. Planktic foraminiferal biostratigraphic events from the classic zonation schemes are recognized here and are generally in good agreement with calibrated stratigraphies, with the exception of the tops of G. nuttalli, A. bullbrooki, and $M$. aragonensis, which occur anomalously high in the section. When considered alongside available calcareous nannofossil datums, there is some disagreement in terms of both the relative ordering and position of calcareous microfossil events, particular with respect to the MECO event, which, in the absence of an independent age model, acts as a key stratigraphic marker. Thus, further calibrations of these bioevents are necessary, particularly from the Pacific Ocean, which is poorly represented in current calibration schemes. Microfossil reworking is also evident in the uppermost $\sim 30 \mathrm{~m}$ of Site 865 above the MECO interval, indicating a dynamic local hydrography capable of remobilizing and mixing sediments during the middle Eocene. ODP Site 865 is the first tropical record where the apparent entirety of the MECO event is preserved in carbonate-bearing sediments, and, despite the reworking at this site, the primary environmental signals are preserved. Thus, ODP Site 865 represents a valuable site for future investigations into environmental and biotic change in the tropics during the MECO.
Data availability. All raw data files are available in the Supplement and also at https://doi.org/10.1594/PANGAEA.920115 (Edgar et al., 2020).

Supplement. The supplement related to this article is available online at: https://doi.org/10.5194/jm-39-117-2020-supplement.

Author contributions. KME conceived and coordinated the study, processed and analysed the samples for stable isotope analysis, developed a revised planktic foraminiferal biostratigraphy, drafted figures, and wrote the article; SMB carried out XRF analyses and constructed the composite depth scales and drafted associated figures; SB conducted spectral analysis, constructed the orbital stratigraphy, and drafted associated figures; PB conducted new calcareous nannofossil analyses; PNP and HKC developed the initial planktic foraminiferal biostratigraphy for this site and contributed to the revised planktic foraminiferal biostratigraphy and taxonomy; CL supported the stable isotope work. All authors contributed to the writing and editing of the article.

Competing interests. The authors declare that they have no conflict of interest.

Acknowledgements. This research used samples provided by the International Ocean Discovery Program (IODP). The authors would like to thank Sandra Nederbragt for technical assistance with $\delta^{18} \mathrm{O}$ and $\delta^{13} \mathrm{C}$ analyses and Cardiff University undergraduate students Bo Fan Peng, Jonathon Gamble, and Holly Welsby for help picking benthic foraminifera.

Financial support. This research has been supported by the Natural Environment Research Council (grant nos. NE/H016457/1 and NE/P013112/1) and the Leverhulme Trust (grant no. ECF-2013608).

Review statement. This paper was edited by Laia Alegret and reviewed by two anonymous referees.

\section{References}

Agnini, C., Fornaciari, E., Giusberti, L., Grandesso, P., Lanci, L., Luciani, V., Muttoni, G., Paelike, H., Rio, D., Spofforth, D. J. A., and Stefani, C.: Integrated biomagnetostratigraphy of the Alano section (NE Italy): A proposal for defining the middlelate Eocene boundary, Geol. Soc. Am. Bull., 123, 841-872, https://doi.org/10.1130/B30158.1, 2011.

Agnini, C., Fornaciari, E., Raffi, I., Catanzariti, R., Pälike, H., Backman, J., and Rio, D.: Biozonation and biochronology of Paleogene calcareous nannofossils from low and middle latitudes, Newsl. Stratigr., 47, 131-181, https://doi.org/10.1127/00780421/2014/0042, 2014. 
Arreguín-Rodríguez, G. J., Alegret, L., and Thomas, E.: Late Paleocene-middle Eocene benthic foraminifera on a Pacific seamount (Allison Guyot, ODP Site 865): Greenhouse climate and superimposed hyperthermal events, Paleoceanography, 31, 346-364, https://doi.org/10.1002/2015PA002837, 2016.

Backman, J.: Quantitative calcareous nannofossil biochronology of middle Eocene through early Oligocene sediment from DSDP Sites 522 and 523, Abhandlungen der Geologischen Bundesanstalt, 39, 21-31, 1987.

Backman, J., Raffi, I., Rio, D., Fornaciari, E., and Pälike, H.: Biozonation and biochronology of Miocene through Pleistocene calcareous nannofossils from low and middle latitudes, Newsl. Stratigr., 47, 131-181, https://doi.org/10.1127/00780421/2014/0042, 2012.

Berggren, W. A. and Pearson, P. N.: A Revised Tropical to Subtropical Paleogene Planktonic Foraminiferal Zonation, J. Foramin. Res., 35, 279-298, https://doi.org/10.2113/35.4.279, 2005.

Berggren, W. A., Kent, D. V., Swisher III, C. C., and Aubry, M.-P.: A revised Cenozoic geochronology and chronostratigraphy, in: Geochronology Time Scales and Global Stratigraphic Correlation, edited by: Berggren, W. A., Kent, D. V., Aubry, M.-P., and Hardenbol, J., SEPM Special Publication, 54, (SEPM) Society for Sedimentary Geology Tulsa, Oklahoma, 129-212, 1995.

Berggren, W. A., Pearson, P. N., Huber, B. T., and Wade, B. S.: Taxonomy, Biostratigraphy, and Phylogeny of Eocene Acarinina, in: Atlas of Eocene Planktonic Foraminifera, 1st Edn., edited by: Pearson, P. N., Olsson, R. K., Huber, B. T., Hemleben, C., and Berggren, W. A., Cushman Foundation Special Publication, 257326, 2006.

Bijl, P. K., Houben, A. J. P., Schouten, S., Bohaty, S. M., Sluijs, A., Reichart, G.-J., Sinninghe Damsté, J. S., and Brinkhuis, H.: Transient Middle Eocene Atmospheric $\mathrm{CO}_{2}$ and Temperature Variations, Science, 330, 819-821, https://doi.org/10.1126/science.1193654, 2010.

Bohaty, S. M. and Zachos, J. C.: Significant Southern Ocean warming event in the late middle Eocene, Geology, 31, 1017-1020, https://doi.org/10.1130/G19800.1, 2003.

Bohaty, S. M., Zachos, J. C., Florindo, F., and Delaney, M. L.: Coupled greenhouse warming and deep-sea acidification in the middle Eocene, Paleoceanography, 24, PA2207, https://doi.org/10.1029/2008PA001676, 2009.

Boscolo Galazzo, F., Thomas, E., Pagani, M., Warren, C., Luciani, V., and Giusberti, L.: The middle Eocene climatic optimum (MECO): A multiproxy record of paleoceanographic changes in the southeast Atlantic (ODP Site 1263, Walvis Ridge), Paleoceanography, 29, 1143-1161, https://doi.org/10.1002/2014PA002670, 2014.

Boscolo Galazzo, F., Thomas, E., and Giusberti, L.: Benthic foraminiferal response to the Middle Eocene Climatic Optimum (MECO) in the South-Eastern Atlantic (ODP Site 1263), Palaeogeogr. Palaeocl., 417, 432-444, https://doi.org/10.1016/j.palaeo.2014.10.004, 2015.

Boulila, S., Vahlenkamp, M., De Vleeschouwer, D., Laskar, J., Yamamoto, Y., Pälike, H., Kirtland Turner, S., Sexton, P., Westerhold, T., and Röhl, U.: Towards a robust and consistent middle Eocene astronomical timescale, Earth Planet. Sc. Lett., 486, 94107, https://doi.org/10.1016/j.eps1.2018.01.003, 2018.

Bown, P.: Palaeogene calcareous nannofossils from the Kilwa and Lindi areas of coastal Tanzania (Tanzania Drilling Project Sites 1 to 10, 2003-4), Journal of Nannoplankton Research, 27, 21-95, 2005.

Bown, P. and Young, J. R.: Techniques, in: Calcareous Nannofossil Biostratigraphy, edited by: Bown, P., British Micropalaeontological Society Series, Chapman and Hall/Kluwer Academic Publishers, London, 18-28, 1998.

Bralower, T. J. and Mutterlose, J.: Calcareous nannofossil biostratigraphy of Site 865, Allison Guyot, central Pacific Ocean: A tropical Paleogene reference section, in: Proceedings of the Ocean Drilling Program, Scientific Results, edited by: Winterer, E. L., Sager, W. W., Firth, J. V., and Sinton, J. M., Ocean Drilling Program, College Station, Texas, 31-74, 1995.

Bralower, T. J., Zachos, J. C., Thomas, E., Parrow, M., Paull, C. K., Kelly, D. C., Silva, I. P., Sliter, W. V., and Lohmann, K. C.: Late Paleocene to Eocene paleoceanography of the equatorial Pacific Ocean: Stable isotopes recorded at Ocean Drilling Program Site 865, Allison Guyot, Paleoceanography, 10, 841-865, https://doi.org/10.1029/95PA01143, 1995.

Coxall, H. K. and Pearson, P. N.: Taxonomy, biostratigraphy, and phylogeny of the Hantkeninidae (Clavigerinella, Hantkenina, and Cribrohantkenina), Cushman Foundation for Foraminiferal Research Special Publication, 41, 213-256, 2006.

Coxall, H. K., Pearson, P. N., Shackleton, N. J., and Hall, M. A.: Hantkeninid depth adaptation: An evolving life strategy in a changing ocean, Geology, 28, 87-90, https://doi.org/10.1130/00917613(2000)28<87:HDAAEL>2.0.CO;2, 2000.

Coxall, H. K., Wilson, P. A., Pearson, P. N., and Sexton, P. F.: Iterative evolution of digitate planktonic foraminifera, Paleobiology, 33, 495-516, https://doi.org/10.1666/06034.1, 2007.

Cramwinckel, M. J., Huber, M., Kocken, I. J., Agnini, C., Bijl, P. K., Bohaty, S. M., Frieling, J., Goldner, A., Hilgen, F. J., Kip, E. L., Peterse, F., van der Ploeg, R., Röhl, U., Schouten, S., and Sluijs, A.: Synchronous tropical and polar temperature evolution in the Eocene, Nature, 559, 382-386, https://doi.org/10.1038/s41586018-0272-2, 2018.

Cramwinckel, M. J., van der Ploeg, R., Bijl, P. K., Peterse, F., Bohaty, S., Röhl, U., Schouten, S., Middleburg, J., and Sluijs, A.: Harmful algae and export production collapse in the equatorial Atlantic during the zenith of Middle Eocene Climatic Optimum warmth, Geology, 47, 247-250, https://doi.org/10.1130/G45614.1, 2019.

Dawber, C. F. and Tripati, A. K.: Constraints on glaciation in the middle Eocene (46-37 Ma) from Ocean Drilling Program (ODP) Site 1209 in the tropical Pacific Ocean, Paleoceanography, 26, PA2208, https://doi.org/10.1029/2010PA002037, 2011.

Dawber, C. F., Tripati, A. K., Gale, A. S., MacNiocaill, C., and Hesselbo, S. P.: Glacioeustasy during the middle Eocene? Insights from the stratigraphy of the Hampshire Basin, UK, Palaeogeogr. Palaeocl., 300, 84-100, https://doi.org/10.1016/j.palaeo.2010.12.012, 2011.

Dutton, A., Lohmann, K. C., and Leckie, R. M.: Insights from the Paleogene tropical Pacific: Foraminiferal stable isotope and elemental results from Site 1209, Shatsky Rise, Paleoceanography, 20, PA3004, https://doi.org/10.1029/2004PA001098, 2005.

Edgar, K. M., Wilson, P. A., Sexton, P. F., and Suganuma, Y.: No extreme bipolar glaciation during the main Eocene calcite compensation shift, Nature, 448, 908-911, https://doi.org/10.1038/nature06053, 2007. 
Edgar, K. M., Wilson, P. A., Sexton, P. F., Gibbs, S. J., Roberts, A. P., and Norris, R. D.: New biostratigraphic, magnetostratigraphic and isotopic insights into the Middle Eocene Climatic Optimum in low latitudes, Palaeogeogr. Palaeocl., 297, 670-682, https://doi.org/10.1016/j.palaeo.2010.09.016, 2010.

Edgar, K. M., Bohaty, S. M., Gibbs, S. J., Sexton, P. F., Norris, R. D., and Wilson, P. A.: Symbiont "bleaching" in planktic foraminifera during the Middle Eocene Climatic Optimum, Geology, 41, 1518, https://doi.org/10.1130/G33388.1, 2013.

Edgar, K. M., Anagnostou, E., Pearson, P. N., and Foster, G. L.: Assessing the impact of diagenesis on $\delta^{11} \mathrm{~B}$, $\delta^{13} \mathrm{C}, \quad \delta^{18} \mathrm{O}, \mathrm{Sr} / \mathrm{Ca}$ and $\mathrm{B} / \mathrm{Ca}$ values in fossil planktic foraminiferal calcite, Geochim. Cosmochim. Ac., 166, 189-209, https://doi.org/10.1016/j.gca.2015.06.018, 2015.

Edgar, K. M., Bohaty, S. M., Coxall, H., Bown, P. R., Batenburg, S. J., Lear, C. H., and Pearson, P. N.: New composite bio- and isotope stratigraphies spanning the Middle Eocene Climatic Optimum at tropical ODP Site 143-865 in the Pacific Ocean, PANGAEA, https://doi.org/10.1594/PANGAEA.920115, 2020.

Expedition 320/321 Scientists: Site U1333, in: Proceedings of the Integrated Ocean Drilling Program, edited by: Pälike, H., Lyle, M., Nishi, H., Raffi, I., Gamage, K., Klaus, A., and Expedition 320/321 Scientists, Integrated Ocean Drilling Program Management International, Inc., Tokyo, 2010.

Fioroni, C., Villa, G., Persico, D., Wise, S. W., and Pea, L.: Revised middle Eocene-upper Oligocene calcareous nannofossil biozonation for the Southern Ocean, Revue de Micropaléontologie, 55, 53-70, https://doi.org/10.1016/j.revmic.2012.03.001, 2012.

Firth, J. V., Eldrett, J. S., Harding, I. C., Coxall, H. K., and Wade, B. S.: Integrated biomagnetochronology for the Palaeogene of ODP Hole 647A: implications for correlating palaeoceanographic events from high to low latitudes, Geol. Soc. Lond. Spec. Publ., 373, 29, https://doi.org/10.1144/SP373.9, 2012.

Fornaciari, E., Agnini, C., Catanzariti, R., Rio, D., Bolla, E. M., and Valvasoni, E.: Mid-latitude calcareous nannofossil biostratigraphy and biochronology across the middle to late Eocene transition, Stratigraphy, 7, 229-264, 2010.

Genin, A., Noble, M., and Lonsdale, P. F.: Tidal currents and anticyclonic motions on two North Pacific seamounts, DeepSea Res. Pt. A, 36, 1803-1815, https://doi.org/10.1016/01980149(89)90113-1, 1989.

Giorgioni, M., Jovane, L., Rego, E. S., Rodelli, D., Frontalini, F., Coccioni, R., Catanzariti, R., and Özcan, E.: Carbon cycle instability and orbital forcing during the Middle Eocene Climatic Optimum, Sci. Rep.-UK, 9, 9357, https://doi.org/10.1038/s41598019-45763-2, 2019.

Gradstein, F. M., Ogg, J. G., Schmitz, M., and Ogg, G.: The Geologic Time Scale 2012, 2-Volume Set, Elsevier, Boston, USA, 2012.

Henehan, M. J., Edgar, K. M., Foster, G. L., Penman, D. E., Hull, P. M., Greenop, R., Anagnostou, E., and Pearson, P. N.: Revisiting the Middle Eocene Climatic Optimum "Carbon Cycle Conundrum" with new estimates of atmospheric $\mathrm{pCO}_{2}$ from boron isotopes, Paleoceanography and Paleoclimatology, 35, e2019PA003713, https://doi.org/10.1029/2019pa003713, 2020.

Holbourn, A., Henderson, A. S., and MacLeod, N.: Atlas of Benthic Foraminifera, Wiley-Blackwell, Chichester, UK, 2013.

Hollis, C. J., Dunkley Jones, T., Anagnostou, E., Bijl, P. K., Cramwinckel, M. J., Cui, Y., Dickens, G. R., Edgar, K. M.,
Eley, Y., Evans, D., Foster, G. L., Frieling, J., Inglis, G. N., Kennedy, E. M., Kozdon, R., Lauretano, V., Lear, C. H., Littler, K., Lourens, L., Meckler, A. N., Naafs, B. D. A., Pälike, H., Pancost, R. D., Pearson, P. N., Röhl, U., Royer, D. L., Salzmann, U., Schubert, B. A., Seebeck, H., Sluijs, A., Speijer, R. P., Stassen, P., Tierney, J., Tripati, A., Wade, B., Westerhold, T., Witkowski, C., Zachos, J. C., Zhang, Y. G., Huber, M., and Lunt, D. J.: The DeepMIP contribution to PMIP4: methodologies for selection, compilation and analysis of latest Paleocene and early Eocene climate proxy data, incorporating version 0.1 of the DeepMIP database, Geosci. Model Dev., 12, 3149-3206, https://doi.org/10.5194/gmd-12-3149-2019, 2019.

Jovane, L., Florindo, F., Coccioni, R., Dinarès-Turell, J., Marsili, A., Monechi, S., Roberts, A. P., and Sprovieri, M.: The middle Eocene climatic optimum event in the Contessa Highway section, Umbrian Apennines, Italy, Geol. Soc. Am. Bull., 119, 413427, https://doi.org/10.1130/B25917.1, 2007.

Jovane, L., Sprovieri, M., Coccioni, R., Florindo, F., Marsili, A., and Laskar, J.: Astronomical calibration of the middle Eocene Contessa Highway section (Gubbio, Italy), Earth Planet. Sc. Lett., 298, 77-88, https://doi.org/10.1016/j.epsl.2010.07.027, 2010.

Kelly, C. D., Bralower, T. J., Zachos, J. C., Silva, I. P., and Thomas, E.: Rapid diversification of planktonic foraminifera in the tropical Pacific (ODP Site 865) during the late Paleocene thermal maximum, Geology, 24, 423-426, https://doi.org/10.1130/00917613(1996)024<0423:RDOPFI>2.3.CO;2, 1996.

Kelly, D. C., Bralower, T. J., and Zachos, J. C.: Evolutionary consequences of the latest Paleocene thermal maximum for tropical planktonic foraminifera, Palaeogeogr. Palaeocl., 141, 139-161, https://doi.org/10.1016/S0031-0182(98)00017-0, 1998.

Kozdon, R., Kelly, D. C., Kita, N. T., Fournelle, J. H., and Valley, J. W.: Planktonic foraminiferal oxygen isotope analysis by ion microprobe technique suggests warm tropical sea surface temperatures during the Early Paleogene, Paleoceanography, 26, PA3206, https://doi.org/10.1029/2010PA002056, 2011.

Kozdon, R., Kelly, D. C., Kitajima, K., Strickland, A., Fournelle, J. H., and Valley, J. W.: In situ $\delta^{18} \mathrm{O}$ and $\mathrm{Mg} / \mathrm{Ca}$ analyses of diagenetic and planktic foraminiferal calcite preserved in a deepsea record of the Paleocene-Eocene thermal maximum, Paleoceanography, 28, 517-528, https://doi.org/10.1002/palo.20048, 2013.

Larrasoaña, J. C., Gonzalvo, C., Molina, E., Monechi, S., Ortiz, S., Tori, F., and Tosquella, J.: Integrated magnetobiochronology of the Early/Middle Eocene transition at Agost (Spain): Implications for defining the Ypresian/Lutetian boundary stratotype, Lethaia, 41, 395-415, https://doi.org/10.1111/j.15023931.2008.00096.x, 2008.

Laskar, J., Gastineau, M., Delise, J.-B., Farrés, A., and Fienga, A.: Strong chaos induced by close encounters with Ceres and Vesta, Astron. Astrophys., 532, L4, https://doi.org/10.1051/00046361/201117504, 2011.

Luciani, V., Giusberti, L., Agnini, C., Fornaciari, E., Rio, D., Spofforth, D. J. A., and Pälike, H.: Ecological and evolutionary response of Tethyan planktonic foraminifera to the middle Eocene climatic optimum (MECO) from the Alano section (NE Italy), Palaeogeogr. Palaeocl., 292, 82-95, https://doi.org/10.1016/j.palaeo.2010.03.029, 2010. 
Maiklem, W. R.: Black and brown speckled foraminiferal sand from the southern part of the great barrier reef, J. Sediment. Petrol., 27, 1023-1030, 1967.

Martini, E.: Standard Tertiary calcareous nannoplankton zonation, in: Proceedings of the II Plankton Conference Roma, edited by: Farninacci, A., Tecnoscienza, Rome, 1971.

Matthews, J. L., Heezen, B. C., Catalano, R., Coogan, A., Tharp, M., Natland, J., and Rawson, M.: Cretaceous Drowning of Reefs on Mid-Pacific and Japanese Guyots, Science, 184, 462-464, https://doi.org/10.1126/science.184.4135.462, 1974.

Meyers, S. R.: Astrochron: An R Package for Astrochronology, available at: https://cran.r-project.org/package=astrochron (last access: 9 July 2020), 2014.

Mita, I.: Data Report: Early to late Eocene calcareous nannofossil assemblages of Sites 1051 and 1052, Blake Nose, North western Atlantic Ocean, in: Proceedings of the Ocean Drilling Program, Scientific Reports, edited by: Kroon, D., Norris, R. D., and Klaus, A., Ocean Drilling Program, College Station, Texas, 1-28, 2001.

Möbius, I., Friedrich, O., Edgar, K. M., and Sexton, P. F.: Episodes of intensified biological productivity in the subtropical Atlantic Ocean during the termination of the Middle Eocene Climatic Optimum, Paleoceanography, 30, 1041-1058, https://doi.org/10.1002/2014PA002673, 2015.

Norris, R. and Nishi, H.: Evolutionary trends in coiling of tropical Paleogene planktic foraminifera, Paleobiology, 27, 327-347, https://doi.org/10.1666/00948373(2001)027<0327:ETICOT>2.0.CO;2, 2001.

Olsson, R. K., Pearson, P. N., and Huber, B. T.: Taxonomy, biostratigraphy and phylogeny of Eocene Catapsydrax, Globorotaloides, Guembelitrioides, Paragloborotalia, Parasubbotina, and Pseudoglobigerinella n. gen., in: Atlas of Eocene Planktonic Foraminifera, 1st Edn., edited by: Pearson, P. N., Olsson, R. K., Huber, B. T., Hemleben, C., Berggren, W. A., and Coxall, H. K., Cushman Foundation Special Publication, Cushman Foundation, Fredericksburg, USA, 67-110, 2006.

Paillard, D., Labeyrie, L., and Yiou, P.: Macintosh Program performs time-series analysis, EOS T. Am. Geophys. Un., 77, 379379, https://doi.org/10.1029/96EO00259, 1996.

Pälike, H., Lyle, M. W., Nishi, H., Raffi, I., Ridgwell, A., Gamage, K., Klaus, A., Acton, G., Anderson, L., Backman, J., Baldauf, J., Beltran, C., Bohaty, S. M., Bown, P., Busch, W., Channell, J. E. T., Chun, C. O. J., Delaney, M., Dewangan, P., Jones, T. D., Edgar, K. M., Evans, H., Fitch, P., Foster, G. L., Gussone, N., Hasegawa, H., Hathorne, E. C., Hayashi, H., Herrle, J. O., Holbourn, A., Hovan, S., Hyeong, K., Iijima, K., Ito, T., Kamikuri, S., Kimoto, K., Kuroda, J., Leon-Rodriguez, L., Malinverno, A., Moore, T. C., Murphy, B. H., Murphy, D. P., Nakamura, H., Ogane, K., Ohneiser, C., Richter, C., Robinson, R., Rohling, E. J., Romero, O., Sawada, K., Scher, H., Schneider, L., Sluijs, A., Takata, H., Tian, J., Tsujimoto, A., Wade, B. S., Westerhold, T., Wilkens, R., Williams, T., Wilson, P. A., Yamamoto, Y., Yamamoto, S., Yamazaki, T., and Zeebe, R. E.: A Cenozoic record of the equatorial Pacific carbonate compensation depth, Nature, 488, 609-614, https://doi.org/10.1038/nature11360, 2012.

Pearson, P. N.: Planktonic foraminifer biostratigraphy and the development of pelagic caps on guyots in the Marshall Islands group, in: Proceedings of the Ocean Drilling Program, Scientific Results, edited by: Haggerty, J. A., Premoli Silva, I., Rack, F., and McNutt, M. K., Ocean Drilling Program, College Station, Texas, 21-59, 1995.

Pearson, P. N. and Ezard, T. H. G.: Evolution and speciation in the Eocene planktonic foraminifer Turborotalia, Paleobiology, 40, 130-143, https://doi.org/10.1666/13004, 2014.

Pearson, P. N. and Palmer, M. R.: Atmospheric carbon dioxide concentrations over the past 60 million years, Nature, 406, 695-699, https://doi.org/10.1038/35021000, 2000.

Pearson, P. N., Ditchfield, P. W., Singano, J., Harcourt-Brown, K. G., Nicholas, C. J., Olsson, R. K., Shackleton, N. J., and Hall, M. A.: Warm tropical sea surface temperatures in the Late Cretaceous and Eocene epochs, Nature, 413, 481-487, https://doi.org/10.1038/35097000, 2001.

Pearson, P. N., Olsson, R. K., Huber, B. T., Hemleben, C., Berggren, W. A., and Coxall, H. K.: Atlas of Eocene Planktonic Foraminifera, Cushman Foundation for Foraminiferal Research Special Publication, Cushman Foundation, Fredericksburg, USA, 513 pp., 2006.

Peterson, L. C. and Backman, J.: Late Cenozoic carbonate accumulation and the history of the carbonate compensation depth in the eastern equatorial Indian Ocean, in: Proceedings of the Ocean Drilling Program, Scientific Results, edited by: Duncan, R. A., Backman, J., and Peterson, L. C., Ocean Drilling Program, College Station, Texas, 467-507, 1990.

Pilkey, O. H., Blackwelder, B. W., Doyle, L. J., Estes, E., and Terlecky, M.: Aspects of carbonate sedimentation on the Atlantic continental shelf of the southern United States, J. Sediment. Petrol., 39, 744-768, 1969.

Premoli Silva, I., Haggerty, J., Rack, F., and Shipboard Scientific Party: Proceedings of the Ocean Drilling Program, Initial Reports, Ocean Drilling Program, College Station, Texas, 1993.

Premoli Silva, I., Wade, B. S., and Pearson, P. N.: Taxonomy, Biostratigraphy, and Phylogeny of Globigerinatheka and Orbulinoides, in: Atlas of Eocene Planktonic Foraminifera, 1st Edn., edited by: Pearson, P. N., Olsson, R. K., Huber, B. T., Hemleben, C., and Berggren, W. A., Cushman Foundation Special Publication, 169-212, 2006.

Rivero-Cuesta, L., Westerhold, T., Agnini, C., Dallanave, E., Wilkens, R. H., and Alegret, L.: Paleoenvironmental Changes at ODP Site 702 (South Atlantic): Anatomy of the Middle Eocene Climatic Optimum, Paleoceanography and Paleoclimatology, 34, 2047-2066, https://doi.org/10.1029/2019PA003806, 2019.

Röhl, U. and Abrams, L. J.: High resolution, downhole, and nondestructive core measurements from sites 999 and 1001 in the Caribbean Sea: Application to the late Paleocene thermal maximum, in: Proceedings of the Ocean Drilling Program, Scientific Results, edited by: Leckie, R. M., Sigurdsson, H., Acton, G. D., and Draper, G., Ocean Drilling Program, College Station, Texas, 191-203, 2000.

Savian, J., Jovane, L., Trindade, R., Frontalini, F., Coccioni, R., Bohaty, S., Wilson, P., Florindo, F., and Roberts, A.: Middle Eocene Climatic Optimum (MECO) in the Monte Cagenero section, central Italy, Latinmag Letters, 3, PC02, 2013.

Savian, J. F., Jovane, L., Giorgioni, M., Iacoviello, F., Rodelli, D., Roberts, A. P., Chang, L., Florindo, F., and Sprovieri, M.: Environmental magnetic implications of magnetofossil occurrence during the Middle Eocene Climatic Optimum (MECO) in pelagic sediments from the equato- 
rial Indian Ocean, Palaeogeogr. Palaeocl., 441, 212-222, https://doi.org/10.1016/j.palaeo.2015.06.029, 2016.

Schulz, M. and Mudelsee, M.: REDFIT: estimating red-noise spectra directly from unevenly spaced paleoclimatic time series, Comput. Geosci., 28, 421-426, https://doi.org/10.1016/S00983004(01)00044-9, 2002.

Sexton, P. F., Wilson, P. A., and Pearson, P. N.: Microstructural and geochemical perspectives on planktic foraminiferal preservation: "Glassy" versus "Frosty", Geochem. Geophy. Geosy., 7, Q12P19, https://doi.org/10.1029/2006GC001291, 2006.

Sexton, P. F., Norris, R. D., Wilson, P. A., Pälike, H., Westerhold, T., Röhl, U., Bolton, C. T., and Gibbs, S.: Eocene global warming events driven by ventilation of oceanic dissolved organic carbon, Nature, 471, 349-352, https://doi.org/10.1038/nature09826, 2011.

Shamrock, J. L.: A new calcareous nannofossil species of the genus Sphenolithus from the Middle Eocene (Lutetian) and its biostratigraphic significance, Journal of Nannoplankton Research, 31, 5$10,2010$.

Shipboard Scientific Party: Site 647, in: Proceedings of the Ocean Drilling Program, Initial Reports, edited by: Srivastava, S. P., Arthur, M. A., Clement, B., and Shipboard Scientific Party, Ocean Drilling Program, College Station, Texas, 1987.

Shipboard Scientific Party: Synthesis of results, in: Proceedings of the Ocean Drilling Program, Initial Reports, edited by: Sager, W. W., Winterer, E. L., Firth, J. V., and Shipboard Scientific Party, Ocean Drilling Program, College Station, Texas, 1993a.

Shipboard Scientific Party: Site 865, in: Proceedings of the Ocean Drilling Program, Initial Reports, edited by: Sager, W. W., Winterer, E. L., Firth, J. V., and Shipboard Scientific Party, Ocean Drilling Program, College Station, Texas, 111-180, 1993b.

Shipboard Scientific Party: Site 1051, in: Proceedings of the Ocean Drilling Program, Initial Reports, edited by: Norris, R. D., Kroon, D., Klaus, A., and Shipboard Scientific Party, Ocean Drilling Program, College Station, Texas, 171-240, 1998.

Shipboard Scientific Party: Site 1209, in: Proceedings Ocean Drilling Program, Initial Reports, edited by: Bralower, T. J., Premoli-Silva, I., Malone, M. J., and Shipboard Scientific Party, Ocean Drilling Program, College Station, Texas, 1-102, 2002.

Shipboard Scientific Party: Site 1260, in: Proceedings of the Ocean Drilling Program, Initial Reports, edited by: Erbacher, J., Mosher, D. C., Malone, M. J., and Shipboard Scientific Party, Ocean Drilling Program, College Station, Texas, 1-113, 2004.

Sluijs, A., Zeebe, R. E., Bijl, P. K., and Bohaty, S. M.: A middle Eocene carbon cycle conundrum, Nat. Geosci., 6, 429, https://doi.org/10.1038/ngeo1807, 2013.

Spofforth, D. J. A., Agnini, C., Pälike, H., Rio, D., Fornaciari, E., Giusberti, L., Luciani, V., Lanci, L., and Muttoni, G.: Organic carbon burial following the middle Eocene climatic optimum in the central western Tethys, Paleoceanography, 25, PA3210, https://doi.org/10.1029/2009PA001738, 2010.

Toffanin, F., Agnini, C., Rio, D., Acton, G., and Westerhold, T.: Middle Eocene to early Oligocene calcareous nannofossil biostratigraphy at IODP Site U1333 (equatorial Pacific), Micropaleontology, 59, 69-82, 2013.

Tori, F. and Monechi, S.: Lutetian calcareous nannofossil events in the Agost section (Spain): implications toward a revision of the Middle Eocene biomagnetostratigraphy, Lethaia, 46, 293-307, https://doi.org/10.1111/let.12008, 2013.
Tripati, A. K. and Elderfield, H.: Abrupt hydrographic changes in the equatorial Pacific and subtropical Atlantic from foraminiferal $\mathrm{Mg} / \mathrm{Ca}$ indicate greenhouse origin for the thermal maximum at the Paleocene-Eocene Boundary, Geochem. Geophy. Geosy., 5, Q02006, https://doi.org/10.1029/2003GC000631, 2004.

Tripati, A. K., Delaney, M. L., Zachos, J. C., Anderson, L. D., Kelly, D. C., and Elderfield, H.: Tropical sea-surface temperature reconstruction for the early Paleogene using $\mathrm{Mg} / \mathrm{Ca}$ ratios of planktonic foraminifera, Paleoceanography, 18, 1101, https://doi.org/10.1029/2003PA000937, 2003.

van Hinsbergen, D. J. J., de Groot, L. V., van Schaik, J., Spakman, W., Bijl, P. K., Sluijs, A., Langereis, C. G., and Brinkhuis, H.: A Paleolatitude Calculator for Paleoclimate Studies, PLoS ONE, 10, e0126946, https://doi.org/10.1371/journal.pone.0126946, 2015.

Villa, G., Fioroni, C., Pea, L., Bohaty, S., and Persico, D.: Middle Eocene-late Oligocene climate variability: Calcareous nannofossil response at Kerguelen Plateau, Site 748, Mar Micropaleontol, 69, 173-192, https://doi.org/10.1016/j.marmicro.2008.07.006, 2008.

Wade, B. S., Pearson, P. N., Berggren, W. A., and Pälike, H.: Review and revision of Cenozoic tropical planktonic foraminiferal biostratigraphy and calibration to the geomagnetic polarity and astronomical time scale, Earth-Sci. Rev., 104, 111-142, https://doi.org/10.1016/j.earscirev.2010.09.003, 2011.

Watkins, D. K., Pearson, P. N., Erba, E., Rack, F., Premoli Silva, I., Bohrmann, H. W., Fenner, J., and Hobbs, P. N.: Stratigraphy and Sediment Accumulation Patterns of the Upper Cenozoic Pelagic Carbonate Caps of Guyots in the Northwestern Pacific Ocean, in: Proceedings of the Ocean Drilling Program Scientific Reports, edited by: Haggerty, J., Premoli Silva, I., Rack, F., and McNutt, M. K., Ocean Drilling Program, College Station, TX, 1995.

Westerhold, T. and Röhl, U.: Orbital pacing of Eocene climate during the Middle Eocene Climate Optimum and the chron $\mathrm{C} 19 \mathrm{r}$ event: Missing link found in the tropical western Atlantic, Geochem. Geophy. Geosy., 14, 4811-4825, https://doi.org/10.1002/ggge.20293, 2013.

Westerhold, T., Röhl, U., Pälike, H., Wilkens, R., Wilson, P. A., and Acton, G.: Orbitally tuned timescale and astronomical forcing in the middle Eocene to early Oligocene, Clim. Past, 10, 955-973, https://doi.org/10.5194/cp-10-955-2014, 2014.

Westerhold, T., Röhl, U., Frederichs, T., Bohaty, S. M., and Zachos, J. C.: Astronomical calibration of the geological timescale: closing the middle Eocene gap, Clim. Past, 11, 1181-1195, https://doi.org/10.5194/cp-11-1181-2015, 2015.

Westerhold, T., Röhl, U., Donner, B., Frederichs, T., Kordesch, W. E. C., Bohaty, S. M., Hodell, D. A., Laskar, J., and Zeebe, R. E.: Late Lutetian Thermal Maximum - Crossing a Thermal Threshold in Earth's Climate System?, Geochem. Geophy. Geosy., 19, 73-82, https://doi.org/10.1002/2017GC007240, 2018 a.

Westerhold, T., Röhl, U., Donner, B., and Zachos, J. C.: Global Extent of Early Eocene Hyperthermal Events: A New Pacific Benthic Foraminiferal Isotope Record From Shatsky Rise (ODP Site 1209), Paleoceanography and Paleoclimatology, 33, 626-642, https://doi.org/10.1029/2017pa003306, 2018b.

Witkowski, J., Bohaty, S. M., Edgar, K. M., and Harwood, D. M.: Rapid fluctuations in mid-latitude siliceous plankton production during the Middle Eocene Climatic Optimum (ODP Site 1051, 
western North Atlantic), Mar. Micropaleontol., 106, 110-129, https://doi.org/10.1016/j.marmicro.2014.01.001, 2014.

Young, J. R., Bown, P. R., and Lees, J. A.: Nannotax3 website, International Nannoplankton Association, available at: http:// www.mikrotax.org/Nannotax3 (last access: 21 September 2019), 2017.
Zachos, J. C., Dickens, G. R., and Zeebe, R. E.: An early Cenozoic perspective on greenhouse warming and carbon-cycle dynamics, Nature, 451, 279-283, https://doi.org/10.1038/nature06588, 2008. 